\title{
How Costly is Corporate Bankruptcy for the CEO?
}

\author{
B. Espen Eckbo \\ Tuck School of Business
}

Karin S. Thorburn

Follow this and additional works at: https://repository.upenn.edu/fnce_papers

Part of the Finance and Financial Management Commons, Labor Relations Commons, and the Strategic Management Policy Commons

\section{Recommended Citation}

Eckbo, B. E., \& Thorburn, K. S. (2016). How Costly is Corporate Bankruptcy for the CEO?. Journal of Financial Economics, 121 (1), 210-229. http://dx.doi.org/10.1016/j.jfineco.2016.03.005

Author Karin S.Thorburn is a full time faculty member of Norwegian School of Economics. She is a visiting professor in the Finance Department of the Wharton School at the University of Pennsylvania.

This paper is posted at ScholarlyCommons. https://repository.upenn.edu/fnce_papers/214

For more information, please contact repository@pobox.upenn.edu. 


\title{
How Costly is Corporate Bankruptcy for the CEO?
}

\begin{abstract}
We examine chief executive officer (CEO) career and compensation changes for large firms filing for Chapter 11. One-third of the incumbent CEOs maintain executive employment, and these CEOs experience a median compensation change of zero. However, incumbent CEOs leaving the executive labor market suffer a compensation loss with a median present value until age 65 of $\$ 7$ million (five times predeparture compensation). The likelihood of leaving decreases with profitability and CEO share ownership. Furthermore, creditor control rights during bankruptcy (through debtor-in-possession financing and large trade credits) are associated with CEO career change. Despite large equity losses (median $\$ 11$ million for incumbents who stay until filing), the median incumbent does not reduce his stock ownership as the firm approaches bankruptcy.
\end{abstract}

\section{Keywords}

founder-incumbent CEO, executive labor market, bankruptcy costs, forced turnover, CEO compensation

Disciplines

Finance and Financial Management | Labor Relations | Strategic Management Policy

\section{Comments}

Author Karin S.Thorburn is a full time faculty member of Norwegian School of Economics. She is a visiting professor in the Finance Department of the Wharton School at the University of Pennsylvania. 


\title{
How costly is corporate bankruptcy for the CEO?
}

\author{
B. Espen Eckbo ${ }^{\mathrm{a}, \mathrm{b}, \mathrm{d}, *}$, Karin S. Thorburn ${ }^{\mathrm{b}, \mathrm{d}, \mathrm{e}, *}$, Wei Wang ${ }^{\mathrm{c}, *}$ \\ ${ }^{a}$ Amos Tuck School of Business, Dartmouth College, Hanover, NH 03755, USA \\ ${ }^{b}$ Norwegian School of Economics, Helleveien 30, 5045 Bergen, Norway \\ ${ }^{c}$ Stephen J.R. Smith School of Business, Queens University, Kingston, Ontario, K7L3N6, Canada \\ ${ }^{d} E C G I, c / o$ the Royal Academies of Belgium, Palace of the Academies, 1000 Brussels, Belgium \\ ${ }^{e}$ CEPR, 33 Great Sutton Street, London EC1V ODX, UK
}

\begin{abstract}
We examine chief executive officer (CEO) career and compensation changes for large firms filing for Chapter 11. One-third of the incumbent CEOs maintain executive employment, and these CEOs experience a median compensation change of zero. However, incumbent CEOs leaving the executive labor market suffer a compensation loss with a median present value until age 65 of $\$ 7$ million (five times pre-departure compensation). The likelihood of leaving decreases with profitability and CEO share ownership. Furthermore, creditor control rights during bankruptcy (through debtor-in-possession financing and large trade credits) are associated with CEO career change. Despite large equity losses (median $\$ 11$ million for incumbents who stay until filing), the median incumbent does not reduce his stock ownership as the firm approaches bankruptcy.
\end{abstract}

JEL classification: G33, G34, M12

Keywords: Founder-incumbent CEO, Executive labor market, Bankruptcy costs, Forced turnover, CEO compensation

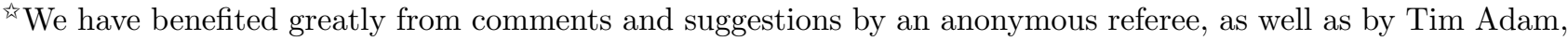
Patrick Altwasser, Naveen Daniel, Fangjian Fu, Michael Hertzel, Wei Jiang, Jun Yang, Si Li, Micah Officer, Lynnette Purda, Armin Schwienbacher, Richard Sweeney, Gloria Tian, and David Yermack, and participants at the finance seminars at BI Norwegian School of Management, Erasmus University, London Business School, Mannheim University, Norwegian School of Economics, Queen's University, Singapore Management University, University of Hong Kong, University of New South Wales, University of Warwick, York University, the annual meetings of American Finance Association, European Finance Association, European Financial Management Association, and Northern Finance Association, and at Drexel Corporate Governance Conference, European Center for Corporate Control Studies, Paris Spring Corporate Finance Conference, Swedish Network for European Studies in Economics and Business Conference, and University of British Columbia Summer Finance Conference. We also thank Xiaoya Ding, Milton Fung, Sam Guo, Matt Murphy, Sammy Singh, Lauren Willoughby, and Hank Yang for research assistance. We are grateful for financial support from the Social Sciences and Humanities Research Council of Canada, Tuck's Lindenauer Center for Corporate Governance, Center for Applied Research at Norwegian School of Economics, and Queen's School of Business Research Program.

${ }^{*}$ Corresponding author: B. Espen Eckbo. Tel.: +1-603-646-3953. E-mail: b.espen.eckbo@tuck.dartmouth.edu.
} 


\section{Introduction}

Corporate bankruptcy can impose personal costs on the firm's chief executive officer (CEO), ranging from forced career change to loss of labor market capital and equity value. These costs are of great interest to corporate finance because they can incentivize CEOs to hedge against bankruptcy risk at the expense of shareholder value. For example, one finds references to this hedging incentive in studies of large corporate cash balances (Bates et al., 2009), near-zero leverage firms (Strebulaev and Yang, 2013), and firms that could switch to low-risk investments when approaching bankruptcy (Eckbo and Thorburn, 2003; Eisdorfer, 2008). The concept of personal costs of corporate bankruptcy is also used in the context of optimal design of nonexecutive labor contracts (Berk et al., 2010; Chemmanur et al., 2013).

Notwithstanding its importance, evidence on CEO personal costs arising from corporate bankruptcy in the US is sparse. Some evidence exists on CEO compensation losses associated with Chapter 11 filings in the 1980s (Gilson, 1989; Gilson and Vetsuypens, 1993). However, over the past decades, Chapter 11 has evolved toward a more creditor-oriented process (Jiang et al., 2012; Ayotte et al., 2013), which by itself can impact CEO personal costs of corporate bankruptcy. In this paper, we provide large-sample evidence on CEO career and compensation changes in the modern era of Chapter 11. With the exception of Eckbo and Thorburn (2003), who use Swedish tax returns to show changes in CEO labor market income after bankruptcy filing, the type of longitudinal employment and compensation change information that we analyze is largely new to the literature on Chapter 11 bankruptcy (Hotchkiss et al., 2008).

Does the executive labor market punish CEOs who file for Chapter 11? The answer is likely complex. On the one hand, the CEO could have paid insufficient attention to the firm's operational and financial policies, including a failure to restructure the untenable set of financial claims against the firm. On the other hand, this criticism could be muted by a realization that forces beyond the CEO's control, such as technological and regulatory changes, also contribute to financial distress. Moreover, the decision to file can be viewed positively by the labor market because it halts further slide toward costly liquidation and adds valuable crisis management experience to the CEO's skill 
set. The net effect of these considerations for CEO career opportunities and changes in CEO labor market capital is a largely unresolved empirical question, which our evidence addresses.

In this paper, we trace CEO employment through bankruptcy and estimate the loss of labor market capital by comparing the CEO's compensation before and after bankruptcy. Our sample consists of 322 Chapter 11 filings in the period 1996 to 2007 by large, publicly traded US companies. We focus on the career changes of the incumbent CEO, defined as the CEO in charge of the firm at the fiscal year-end three years prior to bankruptcy filing (event year -3). Moreover, we single out the $18 \%$ of the incumbents who are company founders. This is somewhat higher than the $11 \%$ founder CEOs reported by Fahlenbrach (2009) for large public US firms outside of bankruptcy.

For comparison, we also include the CEOs hired to replace the incumbents during the bankruptcy event period from year -2 through the year after emergence (event year Emergence+1). One can reasonably expect that the incumbent CEO is more likely to be held responsible for the firm's demise than a replacement CEO hired closer to or after filing. At the same time, a founder incumbent can have firm-specific human capital that is valuable for the distressed firm (Anderson and Reeb, 2003; Fahlenbrach, 2009; Adams et al., 2009).

The analysis is performed in five steps. First, we determine to what extent the CEO continues at the helm of the restructured firm or leaves over the bankruptcy event period. CEO turnover is high. Of the 322 incumbents, $86 \%$ leave before year-end Emergence +1 . The departures are classified as either voluntary or forced, defined as performance-related or following pressure from the board, shareholders, or creditors. We find that founder incumbents are marginally less likely to be forced out than nonfounder incumbents. Moreover, forced turnover increases with fraud allegations and with creditor control rights during bankruptcy. A channel for the latter effect is covenants imposed by debtor-in-possession (DIP) financing lenders. Multivariate regressions further indicate that CEOs with greater percentage share ownership are less likely to leave the firm voluntarily, as if equity ownership provides an incentive to stay with the firm as it approaches bankruptcy.

Second, for a CEO who leaves his position, we record any new employment within three years 
using public sources such as industry manuals, press releases, and social media. We positively identify the employment or retirement for $81 \%$ of the 322 incumbent CEOs and classify the remaining 19\% as retired. Approximately one-third of all incumbent CEOs leave for a new executive position or remain CEO of the restructured firm after emergence. The remaining two-thirds leave the executive labor market to assume nonexecutive directorships on corporate boards, become consultants, or retire. The likelihood of leaving the executive labor market is positively associated with relatively poor operating performance, DIP financing, and allegations of financial fraud. While incumbent CEOs are more likely to leave without assuming a new executive position than replacement CEOs, no significant difference emerges in the full sample between founders and nonfounders.

Third, we find the CEO's compensation in his new career and compare that with his compensation at the bankrupt firm. For CEOs who continue as executives at public firms, we collect the new compensation from ExecuComp or Securities and Exchange Commission (SEC) filings (proxy statements and form 10-K). For those who become executives at private firms, we follow the literature and estimate the new compensation as the executive compensation for a public company matched on two-digit standard industrial classification (SIC) industry and size (Core et al., 1999; Murphy, 1999; Harford and Li, 2007; Kaplan and Rau, 2010), adjusted by a 20\% private-firm discount (Gao et al., 2011; Gao and Li, 2015).

We compute the present value (PV) of the compensation change (new minus old) through age 65 as a measure of the effect of the bankruptcy event on the CEO's labor market capital. As some CEOs retire voluntarily, this PV represents an upper bound on the incumbent CEO's change in labor market capital due to bankruptcy. For incumbents (founders as well as nonfounders) who maintain executive employment, the median estimated compensation change is statistically indistinguishable from zero. This holds regardless of whether the CEO stays with the restructured firm or assumes an executive position at another firm. Thus, the executive labor market capital of these incumbents is typically unaffected by bankruptcy filing. In contrast, incumbents who leave the executive labor market experience a substantial compensation loss, with a median PV 
estimate of $\$ 7.2$ million or 4.6 times the old compensation in constant 2009 dollars.

Fourth, we measure the CEO's loss on his equity holdings in the bankrupt firm. For incumbents who stay until the year of bankruptcy filing, the median equity value declines from $\$ 11$ million in year -3 to $\$ 2$ million in year -1 . Notwithstanding this drop, their median percent share ownership stays constant at $3 \%$ over the pre-filing period. Because only about $15 \%$ of the incumbent CEOs receive restricted stock awards, this suggests that they typically do not sell out prior to bankruptcy filing.

We end the paper with a brief multivariate examination of CEO compensation at the distressed firm prior to filing, comparing incumbents with replacement hires. Controlling for CEO and firm-specific characteristics, we find that incumbents (founders as well as nonfounders) are paid significantly more than replacement CEOs, suggesting the existence of a rent component in the incumbents' compensation. One of the key results of this paper, that the median compensation does not change for incumbents who depart for new executive positions, suggests that this rent component (if it exists) is not specific to the filing firm. That is, this subsample of departing CEOs could generally be of a high quality relative to the replacements CEOs, for reasons that are not captured by the regression determinants. We are unable to resolve whether or not the incumbents who end up leaving the executive labor market earn rents specific to the filing firm.

The remainder of the paper is organized as follows. Section 2 describes the sample selection procedure and our choice of CEO, firm, and bankruptcy characteristics for the cross-sectional empirical analysis. We then proceed with presenting our evidence on CEO turnover and new employment in Section 3 and 4, respectively, followed by the CEO compensation change and equity value loss evidence in Section 5. Section 6 contains the compensation comparison of incumbents and replacement CEOs, and Section 7 concludes the paper.

\section{Chapter 11 filings and empirical test strategy}

This section describes the sample selection and defines the variables used in our empirical analysis below. 


\subsection{Sample selection}

Our sample selection starts with 497 Chapter 11 filings in the 1996 to 2007 period by US firms with book assets above $\$ 100$ million (in constant 1980 dollars) from the Bankruptcy Research Database of Professor Lynn LoPucki at the University of California at Los Angeles (UCLA). We require the firm to be publicly traded, the bankruptcy case to be resolved by year-end 2010 (eliminating five protracted cases), and information on CEO characteristics and compensation to be available in the fiscal year prior to filing. These restrictions jointly eliminate 175 cases, for a final sample of 322 bankrupt firms.

We track each sample firm over an event window that begins in year -3 relative to the fiscal year of Chapter 11 filing (year 0). If the firm successfully reorganizes in Chapter 11, the event window ends in the year after emergence (Emergence+1), where Emergence is the year that the reorganization plan is confirmed by the bankruptcy court. If the firm is liquidated (liquidation) or sold (acquisition) in bankruptcy instead of being reorganized, the event period ends with these outcomes. This yields a total of 1,899 firm-year observations from the period 1993 through 2010 .

Table 1 presents the annual distribution and characteristics of our sample firms. Dollar values are in constant 2009 dollars throughout the paper. As expected, the number of filings is relatively high over the two years following the market-wide economic decline in 2000. Moreover, filing firms are relatively large, with average sales of $\$ 2.5$ billion and total assets of $\$ 3.4$ billion (both with median of $\$ 0.8$ billion) at the end of the year prior to filing (year -1 ).

$* * * * * * * * * * * * * * * * * *$ Insert Table 1 near here

Table 1 further shows that the filing firm emerges from Chapter 11 as a stand-alone restructured company in 205 cases (64\%), and 85 firms (26\%) are liquidated and another 32 firms (10\%) are acquired in bankruptcy. The duration of the bankruptcy proceedings, defined as the time between filing and emergence, liquidation, or acquisition, is 17 months on average (median 13 months). About half of the cases are resolved within 12 months of filing and $78 \%$ are resolved within 24 months. Thirty percent of the bankruptcies are prepacks. A prepack is a prepackaged bankruptcy filing, in which the firm files a plan of reorganization jointly with its bankruptcy petition. These 
bankruptcy proceedings tend to be quicker (Tashjian et al., 1996; Thorburn, 2000), and the average time in bankruptcy is only six months (median four months) for the prepacks in our sample. The sample firms are distributed across a large number of two-digit SIC industries. The four largest industries are communications (14\%), business services (5\%), primary metals (5\%), and health services $(5 \%)$.

While not shown in the table, the sample firms struggle financially in the years leading up to filing, with high leverage and poor operating performance compared with their industry peers. The median leverage ratio (defined as total liabilities to total assets) is $82 \%$ in year -2 and $95 \%$ in year -1, which is significantly higher than the industry median. Moreover, the industry-adjusted return on assets [ROA, defined as earnings before interest, taxes, depreciation, and amortization (EBITDA) to total assets] is $-3.5 \%$ and $-5.8 \%$ in years -2 and -1 , respectively, implying a significantly lower operating performance than that of their industry competitors.

\subsection{CEO, firm, and bankruptcy characteristics for the cross-sectional analyses}

Throughout the paper, we use data from our sample firms to perform cross-sectional regressions addressing key aspects of the CEO labor market reaction to financial distress and bankruptcy. First, we estimate the determinants of CEO turnover and of continued executive employment at the sample firm or at another firm. These probabilities address the existence of job opportunities for the CEOs of bankrupt firms, but not their pay levels. Second, we estimate the determinants of the CEO compensation changes around bankruptcy, both when the CEO remains with the restructured firm and following departure from the bankrupt firm. This estimation addresses the key question of the paper: the size and determinants of the change in the total CEO compensation and value of labor-market capital around bankruptcy.

Table 2 defines the variables used in the regressions and their data sources, and Table 3 shows mean and median values of the key CEO, firm, and bankruptcy characteristics in year -3. Much as Gilson (1989) and Hotchkiss (1995), we focus the analysis on the CEOs in place in year -3, here represented by the dummy variable Incumbent. Our main inferences remain unchanged if we instead define an incumbent as being in place two years prior to filing. Moreover, we separate 
founder from nonfounder incumbents. In event year -3, the average CEO tenure is eight years for founder incumbents and five years for nonfounder incumbents. The CEO's tenure with the firm is an alternative measure for his firm-specific human capital. However, including tenure as an additional explanatory variable in the cross-sectional analysis does not materially affect the results.

******************** Insert Tables $2 \& 3$ near here $* * * * * * * * * * * * * * * * * *$

The CEO characteristics also include CEO age (Age), a dummy for the CEO being chairman of the board (Chairman), and the percent of the firm's shares owned by the CEO (Share owner ship). As shown in Table 3, relative to nonfounder incumbents, founders are slightly younger (50 versus 53 years), own more equity (14\% versus 5\%), and more often hold the chairmanship ( $74 \%$ versus $58 \%)$.

The firm characteristics include Size (log of total sales), as well as Cash (cash and short-term investments) and Tangibility (net property, plant, and equipment), both normalized by total assets. Moreover, Industry-adjusted ROA and Industry-adjusted leverage adjust the firm's ROA (EBITDA scaled by book assets) and leverage (total liabilities to book assets) with the two-digit SIC industry median. Industry distress is a dummy variable indicating that the median stock return in the firm's two-digit SIC industry is below -30\% (Opler and Titman, 1994; Acharya et al., 2007). As shown in Table 3, 11\% of the sample firms are in industries classified as distressed in year -3 .

Our analysis also controls for characteristics capturing the potential for creditor control in bankruptcy. Jensen and Meckling (1976) warn that the CEO can implement shareholder-friendly risk-shifting strategies in financial distress. In our context, if such risk shifting fails to avoid bankruptcy, creditors bear the brunt of the costs and can hold the CEO personally responsible. Creditors have the power to influence the decision to retain the CEO in Chapter 11, both through voting and use of DIP loan contract provisions. To illustrate, in Recoton's 2003 bankruptcy filing, DIP lenders demanded replacement of the incumbent CEO with outsider Jerry Kalov and included a covenant making removal of Kalov a default on the DIP facility. More generally, DIP 
lenders exert substantial power over the bankrupt firm's day-to-day decisions through use of tight covenants (Dahiya et al., 2003; Skeel, 2003; Li et al., 2013).

Different creditor classes can have different views of the value of keeping the CEO. For example, suppliers trying to save valuable customer relations and secure continued business can use their influence to retain the incumbent CEO. A case in point is the 2007 filing by Hancock Fabrics, in which the suppliers formed an unsecured creditors' committee to ensure that the pre-filing CEO Jane Aggers was retained. In general, because post-petition claims enjoy administrative claim status with priority over general unsecured claims in Chapter 11, suppliers often continue to support their customers by extending short-term credit (Kolay et al., 2015). Moreover, suppliers tend to experience a large reduction in value when their customers file for bankruptcy (Hertzel et al., 2008).

To capture these potential effects, we use four dummy variables reflecting the strength of various claim holders that can influence the bankruptcy process. Institutional ownership indicates that institutional investors own more than $20 \%$ of the firm's equity in the previous year, the sample average in event year -1 . Bond debt and Trade credit indicate that the bankrupt firm has public bonds and non-interest-bearing debt (primarily trade credit), respectively, exceeding two-thirds of total liabilities. Bond debt captures the potential for hedge funds and other distressed investors to influence the restructuring process (Jiang et al., 2012). Trade credit, which is often found among firms in the retail and construction sectors, identifies firms in which unsecured creditors have a particular interest in the survival of the firm. DIP financing indicates that the firm receives debtor-in-possession financing in Chapter 11. In our sample, the pairwise correlation between DIP financing and Trade credit is low.

In addition, we include the dummy variables During bankruptcy, indicating the event window from year 0 through the year of emergence (Emergence), Fraud, indicating financial fraud allegations against the company, and Prepack, indicating that the firm has negotiated a prepackaged bankruptcy filing. Firms filing prepacks tend to have higher going-concern value and debt recovery rates than those selecting a regular (non-prepack) Chapter 11 filing, which in turn could affect 
equilibrium CEO compensation.

\section{CEO turnover and creditor control rights}

The probability that the incumbent CEO leaves the executive labor market around bankruptcy filing is an important driver of his expected personal costs of corporate bankruptcy. Moreover, the response of the $\mathrm{CEO}$ labor market to the bankruptcy event, and the resulting change in executive labor market capital, likely depends on whether the CEO leaves voluntarily or is forced out. To examine this issue, in this section, we provide turnover statistics and estimate the determinants of forced and voluntary turnover, including the role played by creditor control rights.

\subsection{CEO turnover statistics}

We record information on CEO turnover and appointments throughout the reorganization process, relying on SEC filings and, for firms that stop filing with the SEC after entering bankruptcy, bankruptcydata.com and Factiva. Table 4 reports annual CEO departure and appointment frequencies over the event period, separating incumbent and replacement CEOs. There are 322 incumbents, of which 58 are company founders, and 320 CEOs hired to replace the departing executive, for a total of 642 CEOs in the sample. Over the event period (-2, Emergence+1), 144 firms replace a single CEO, 99 firms replace two CEOs, and 34 firms replace three or more CEOs.

******************* Insert Table 4 near here $* * * * * * * * * * * * * * * * * * *$

As shown in Column 5, 277 or $86 \%$ of the incumbents ( $83 \%$ of the founder incumbents) have left the CEO position by the end of year Emergence+1. Thus, $14 \%$ of the incumbent CEOs remain with the restructured firm after it has emerged from bankruptcy. In comparison, Gilson (1989) reports that $29 \%$ of the incumbent CEOs remain with the firm throughout bankruptcy restructuring, and Hotchkiss (1995) reports an incumbent CEO retention rate of 30\%. The higher retention rates reflect that these studies follow CEOs in place two year priors to filing, instead of the three years used to define incumbents in our study.

Of the 320 replacement CEOs, 126 are internally promoted and 194 are hired from the outside. Media reports indicate that one-third of the external replacement CEOs are restructuring 
specialists and two-thirds have prior experience as CEO. As reported in Column 6, 170 (53\%) of the replacement CEOs depart during the bankruptcy event period. In total, 447 of all sample CEOs (incumbents and replacements) leave the sample firm (Column 4).

Of the 447 departing CEOs, 143 leave during the two years leading up to filing, 259 leave during bankruptcy, and the remaining 45 depart in year Emergence+1. This translates into an average annual turnover rate of $30 \%$ over the event period. This rate is comparable to that reported elsewhere for firms in financial distress (Ayotte and Morrison, 2009; Jiang et al., 2012). The turnover rate is highest during bankruptcy, with $39 \%$ of the CEOs replaced in an average year. Prior to filing and after emergence, however, the annual turnover rate averages $22 \%$, which is similar to that reported for solvent firms (Huson et al., 2004; Jenter and Kanaan, 2014).

Table 5 lists the frequency distribution of the reasons for CEO turnover as stated in press releases and news articles (Weisbach, 1988; Warner et al., 1988; Gilson, 1989; Denis and Denis, 1995). These sources identify the reason for departure for $91 \%$ of the CEOs who leave over the bankruptcy event period. The most frequently stated reasons are personal (21\%), liquidation or acquisition $(19 \%)$, retirement or normal succession $(15 \%)$, and pressure from the board, shareholders, or creditors (14\%). We classify turnover as forced if it is performance-related or follows pressure by the board, shareholders, or creditors. With this definition, $18 \%$ of all departures are forced. Not surprisingly, the fraction of forced turnover is significantly higher for incumbents than for replacement CEOs (21\% versus 12\%).

******************** Insert Table 5 near here $* * * * * * * * * * * * * * * * * *$

The extant literature on CEO turnover uses a weaker definition of forced, adding cases in which the departing $\mathrm{CEO}$ is under 60 years old and the departure is for personal reasons and to pursue other interests (Denis and Denis, 1995; Parrino, 1997; Huson et al., 2001; Yermack, 2006; Goldman and Huang, 2014). In our sample, the average CEO age at departure is 55 years (56 years for incumbents and 54 years for replacement CEOs) and three-quarters of the departing CEOs are under 60 years old. Relaxing our strict definition of forced to also include cases in which the CEO is under than 60 years old and resigns for personal reasons or leaves to pursue other interests 
(labeled "weakly forced" in Table 5) increases the fraction of forced departures from $18 \%$ to $44 \%$ ( $47 \%$ for incumbents). To minimize the risk of falsely classifying a departure as forced (Denis and Denis, 1995), we use the stricter definition of forced turnover in our analysis. However, our main inferences concerning CEO turnover also hold for weakly forced turnover.

\subsection{Determinants of forced and voluntary turnover}

Table 6 presents coefficient estimates from multinomial logit regressions for the probability of CEO turnover. The dependent variable has three outcomes: voluntary turnover, forced turnover, and no turnover (the reference outcome). The table presents three models, in which the second model replaces Incumbent with Founder incumbent and Nonfounder incumbent. In the first two models, the sample covers 1,187 firm-years from year -2 through Emergence+1 (237 voluntary and 66 forced CEO turnover firm-years). Because the decision to do a prepacked filing is endogenous and can bias the other coefficients, the third model is limited to the 829 firm-years for non-prepack filings. The regressions include Fama and French 12 (FF12) industry dummies.

******************* Insert Table 6 near here $* * * * * * * * * * * * * * * * * * *$

The probability of voluntary departure (the first column of each model) is significantly associated with three of the four CEO characteristics. That is, it increases with Age and decreases with Chairman and Share ownership. A consistent interpretation is that older executives are more inclined to withdraw from the distressed company rather than partake in the restructuring and that relatively powerful CEOs are less likely to leave voluntarily.

Of the firm and bankruptcy characteristics, only Industry-adjusted ROA is strongly related to the probability of voluntary departure. CEOs are more likely to voluntarily leave firms with relatively weak operating performance (at the 1\% level for the full sample in Models 1 and 2). The significance of operating performance for CEO turnover complements extant evidence on CEO turnover outside of bankruptcy (Huson et al., 2001).

The determinants of the probability of forced CEO turnover (second column of each model) are significantly higher for incumbent than for replacement CEOs. This effect is driven by the nonfounder incumbents (the P-value for the difference of the coefficients for founder and nonfounder 
incumbents is 0.056). One possible explanation is that founders have more firm-specific human capital of value to the distressed firm than nonfounder incumbents. Another is that high equity ownership allows entrenched founder incumbents to retain their positions longer than nonfounder incumbents (the pairwise correlation between Founder incumbent and Share ownership is 0.22). However, such an entrenchment effect, if present, is already controlled for by the inclusion of Share ownership in Table 6.

Among the firm characteristics, forced turnover increases with Size, and it decreases with Industry-adjusted ROA and Trade credit. Among the bankruptcy characteristics, forced departure is significantly higher during bankruptcy proceedings, for firms with DIP financing, and when financial fraud allegations have been lodged against the firm. The significance of Trade credit and DIP financing in particular, and During bankruptcy in general, suggests that the probability of forced turnover increases with the shift in control rights from shareholders to creditors as the firm approaches bankruptcy.

The opposite impact of DIP financing and trade credit on forced turnover could seem surprising. After all, firms relying heavily on trade credit financing, such as retail firms, could require a cash infusion in the form of DIP financing during bankruptcy. However, while trade credit is the primary component of Trade credit, this variable also contains other non-interest-bearing debts, such as pension and tax liabilities (see Table 2). In our data, the correlation between an indicator for DIP financing and trade credit to total liabilities is only 0.14 , and it is even lower in Table 6 where Trade credit is a dummy. What Table 6 shows is that the effect of Trade credit on forced turnover is negative after controlling for the positive effect of DIP financing. This result is consistent with trade creditors having developed strong economic ties with the firm and its CEO as part of an efficient supply chain. Alternatively, dispersed trade creditors can simply face coordination problems that weaken their bargaining power in bankruptcy and lowers the likelihood of forced CEO departure.

As shown in Table 1, prepacks are typically resolved more quickly than regular Chapter 11 filings, perhaps reflecting that the firm is somewhat less distressed or has a less complex claim 
structure. Nevertheless, the indicator variable Prepack is insignificant in Models 1 and 2, suggesting that CEOs of prepack firms have a similar likelihood of being forced out as CEOs of non-prepack firms. However, eliminating the prepack firms from the regression (Model 3) reduces the significance of Size and Industry-adjusted ROA. This result is in part a consequence of eliminating relatively profitable firms from the sample, which lowers the remaining cross-sectional variation in firm profitability.

In sum, the likelihood of voluntary turnover increases with CEO age, and it decreases with firm operating performance, CEO share ownership, and the chairmanship dummy. This evidence suggests that relatively powerful CEOs and CEOs of firms performing relatively well are less likely to leave voluntarily. Moreover, in the full sample, the likelihood of forced CEO turnover decreases with operating performance and the trade credit dummy, and it is higher for nonfounder incumbents, when there are allegations of financial fraud, during bankruptcy, and for firms receiving DIP financing. The decision to fire the CEO thus could be associated with the increase in creditor control rights that results from bankruptcy filing.

\section{Quo vadis? CEO new employment and career changes}

The question posed in the title of this paper requires estimation of how bankruptcy filing changes CEO employment and his compensation conditional on the employment change. Fig. 1 shows the basic structure that we use for this analysis. We begin this section by identifying and describing the main determinants of three key CEO employment outcomes: (1) remain at the restructured firm, (2) depart to another executive position, and (3) depart for no new executive position. In Section 5, we estimate the conditional compensation changes and their determinants. This analysis allows us to infer both the extent to which bankruptcy forces CEO career changes and the costs of those changes.

$* * * * * * * * * * * * * * * * * *$ Insert Figure 1 near here $* * * * * * * * * * * * * * * * * *$ 


\subsection{Identifying new employment}

From Table 4, of the total sample of 642 incumbent and replacement CEOs, 447 leave their executive position at the bankrupt firm. Moreover, proxy statements and 10-Ks show that 190 of the sample CEOs remain as top executives of the restructured firm at year-end Emergence+1. We are unable to determine the departure status for five of the replacement CEOs. We further eliminate 30 CEOs hired after emergence. As listed to the left in Fig. 1, this yields a sample of 322 incumbent CEOs, and 607 CEOs when including the replacements CEOs (in parentheses), for the employment change analysis.

For CEOs who leave (lower branch in the figure), we search for new employment over the next three years, including directorship at the restructured firm. The sources of this information include the sample firms' proxy statements and 10-Ks, corporate registries [Standard \& Poor's (S\&P) Corporate Register and Marquis Who's Who in Finance and Business], news and press releases (Factiva), and Internet searches (LinkedIn, Wikipedia, and Google). If we fail to find employment information in any of these sources, we classify the CEO as having no new employment. This search positively identifies career-related information for $81 \%$ of the incumbents and $83 \%$ when including CEOs who remain with the restructured firm. These identification rates are high by the extant literature tracking CEO career changes (Gilson, 1989; Fee and Hadlock, 2003, 2004; Desai et al., 2006).

Fig. 1 summarizes the frequencies of various employment change categories for incumbent CEOs and for the sample including replacement CEOs (in parentheses). From Table 4, 14\% of the incumbents remain with the restructured firm at year-end Emergence +1 . Of the $86 \%$ of incumbents who leave, $21 \%$ assume a new executive position (5\% become CEOs at other public firms, $8 \%$ become CEOs at private firms, $1 \%$ become nonCEO executives at public firms, and $6 \%$ become nonCEO executives at private firms). Conditional on a new executive position, it takes on average one year before the CEO joins another firm. Overall, a total of $32 \%$ of the 322 incumbent CEOs (31\% of the founders) maintain executive employment. Including replacement CEOs, the percentage is $45 \%$. 
The new firms hiring the departing CEOs tend to be of similar size as the bankrupt firm in terms of total sales (whether public or private and measured at the years of departure and rehiring). However, two-thirds of the new firms are in a different two-digit SIC industry. Thus, only a minority of the CEOs who leave for a new executive position maintain their broad industry specialization.

We next consider the $79 \%$ of the departing incumbent CEOs who leave the executive labor market entirely (lowest branch in Fig. 1). These CEOs become nonexecutive directors (21\%), are consultants or self-employed (16\%), or are classified as having no new employment (42\%). As to the last category, our data sources confirm this status for about half of the CEOs, primarily indicating retirement or honorary chairman of the bankrupt firm. For the other half of the CEOs classified as no new employment, we cannot be certain whether these CEOs fail to find new employment or decide to pursue other personal (nonlabor market) interests. Having said that, if someone assumes an executive position, it is likely to trigger information releases in company reports, industry manuals, news articles, press releases, and websites, all of which are included in our search. In sum, one-third of the incumbent CEOs, whether founder or nonfounder, retain their position at the restructured firm or move to a new executive position at another firm.

\subsection{Determinants of $C E O$ career changes}

Table 7 reports coefficients in multinomial logit regressions in which the dependent variable has three outcomes: departure to a new executive position, departure without a new executive position (leaving the executive labor market), and no departure (the reference outcome). The sample and explanatory variables are the same as in Table 6 . Eliminating the $17 \%$ of the sample CEOs with missing information on new employment (Subsection 4.1) leaves inferences from the regression analysis in this subsection unchanged.

******************** Insert Table 7 near here $* * * * * * * * * * * * * * * * * *$

Beginning with the likelihood of departing to a new executive position, the only significant variable is Trade credit, which receives a negative coefficient. The supply chain of a firm with substantial trade credit can involve a relatively high level of firm-specific CEO capital. This could 
explain why trade credit is associated with a lower probability that the CEO leaves. Moreover, the insignificance of the remaining explanatory variables suggests that the characteristics determining CEO executive labor market capital are similar across the old and the new firms, although only the former are financially distressed. With this interpretation, one would also expect the equilibrium CEO pay to be (conditionally) similar across old and new firms, which is what we find.

We next turn to the probability that the CEO departs with no new executive position (second column of each model in Table 7). Because the CEO turnover probability is embedded in the likelihood that the CEO leaves the executive labor market, several of the significant determinants of this probability are the same as those found in Table 6. In particular, just as nonfounder incumbents have a greater likelihood than replacement CEOs of being forced out, these CEOs have a greater probability of leaving the executive labor market (Models 1 and 2). In the nonprepack sample (Model 3), nonfounder CEOs also have a significantly greater likelihood than founder CEOs of leaving the executive labor market.

Among the CEO and firm characteristics, the probability of departing without new executive employment increases with Age, and it decreases with Share ownership and Industry-adjusted $R O A$. The effect of age in part reflects retirements. In Table 6, voluntary turnover decreases with CEO share ownership and operating performance, which in part drives the significance of these variables in Table 7. Finally, the likelihood of leaving the executive labor market is higher when allegations of financial fraud have arisen against the firm.

Finally, much as in Table 6 for the probability of forced CEO turnover, creditor control rights appear to influence the probability of leaving the executive labor market in Table 7. However, the effect now depends on whether the sample includes prepack firms. In the full sample, DIP financing is positive and highly significant. In the nonprepack sample, During bankruptcy appears to subsume this effect. The significance of During bankruptcy in the nonprepack sample reflects the Chapter 11 bankruptcy process with its active exercise of creditor rights. 


\section{CEO bankruptcy costs: compensation change and equity loss}

In this section, we follow the structure of the main outcomes in Fig. 1 and show the CEO's compensation change when he remains at the helm of the restructured firm, moves to a new firm, or leaves the executive labor market altogether. Moreover, to estimate the CEO's overall economic costs, we show his loss of equity investment value in the distressed firm.

\subsection{Measuring CEO compensation}

For each CEO, we collect information on the CEO's annual compensation, stocks beneficially owned (percent and dollar value), and number and value of unexercised options. Compensation data are available for 1,351 firm-years. Of these, $18 \%$ are from ExecuComp and $82 \%$ are obtained manually from SEC filings (proxy statements and 10-K forms) via EDGAR (Electronic Data Gathering, Analysis, and Retrieval system). CEO compensation is defined as the sum of cash pay (salary, bonus, long-term incentive plans, and other annual cash compensation), new equity grants (restricted stock awards and Black and Scholes value of option grants), and all other compensation.

The value of restricted stock grants is from the compensation table in proxy statements and 10Ks. Option grants are valued using Black and Scholes and following Core and Guay (1999). Among the parameter values, stock return volatility is measured as the annualized standard deviation of daily stock returns over the fiscal year of the grant. For firms with fewer than 50 daily stock returns, we use the median volatility for all ExecuComp firms in that year. The volatility is winsorized at the 5th and 95th percentile each year. The dividend yield is the ratio of cash dividends to the fiscal year-end stock price, and the risk-free rate is the Treasury bond yield corresponding to the option's expected time to maturity.

The compensation change is the difference between the CEO compensation at the new and old (sample) firm. For the incumbent CEOs, the old compensation is averaged over years -3 and -2 to smooth temporary income fluctuations (when the income in year -3 is missing, it is the income in year -2 only). For the replacement CEOs, the old compensation is averaged over the hiring year and the next (or, when the income in the next year is missing, it is the income in the hiring 
year only). The idea is to smooth temporary influences caused by signing bonuses, partial-year employment in the first year of hire, and restructuring bonuses. However, restricting the analysis to the year after hiring does not affect the median old income for the replacement CEOs. Data to compute the old compensation are missing for $63 \mathrm{CEOs,} \mathrm{reducing} \mathrm{the} \mathrm{sample} \mathrm{to} 544$ CEOs.

\subsection{Estimating the CEO's new compensation}

Table 8 summarizes our estimation of the CEO's new compensation, beginning with the 110 cases in Panel A, where the CEO's new employment is at a public firm. For these cases, we record the actual new CEO compensation from ExecuComp, proxy statements, and 10-Ks. When the CEO remains with the restructured firm, we use the compensation averaged over years Emergence +1 and Emergence +2 . When the CEO departs to another public firm, the new compensation is the average pay over the year of hiring and the next. Again, the idea is to smooth temporary influences of signing and restructuring bonuses. However, the median of this average pay is statistically indistinguishable from the median pay in the first full year of new employment.

$* * * * * * * * * * * * * * * * * *$ Insert Table 8 near here $* * * * * * * * * * * * * * * * * *$

For the 123 cases in Panel B, where the CEO's new employment is at a private firm, the new compensation is estimated using the pay at a two-digit SIC industry and sales-matched firm in ExecuComp, adjusted with a 20\% private-firm discount (Gao et al., 2011; Gao and Li, 2015). The sales of the matched firm must be within $30 \%$ of the private firm's sales. If sales are missing for the private firm, or no ExecuComp firm in the two-digit industry has sales within the $30 \%$ band, the private firm is matched on assets using the same algorithm. If information on assets is also missing, we match on the number of employees. Data for the private firm are from Capital IQ, Factiva, Wikipedia, and Google. We match the firm in the year that the departed CEO joins the new firm or, if the CEO stays with the restructured firm, in year Emergence+1. For the 28 CEOs in Panel B who depart to a nonCEO executive position, we use the average nonCEO compensation of the matched firm.

As a robustness check, we apply this matching procedure to the CEOs of public firms in Panel A. The matching produces an estimated median CEO compensation that is indistinguishable 
from the actual median compensation of the public firm CEOs. This alleviates concerns that the matching procedure produces an upward bias when applied to private firms.

For the 311 CEOs who leave the executive labor market (Panel C of Table 8), no standard data sources identify the new income. As shown in Fig. 1, we categorize these CEOs into three groups: nonexecutive director, consultant or self-employed, and no new employment.

For the 75 CEOs becoming nonexecutive directors, we use the following ordinary least squares regression models to compute the new compensation, estimated across all ExecuComp firms over the period 2005 to 2012 (in constant 2009 dollars). The models capture the finding of the broader literature that firm size and industry are primary determinants of compensation (Frydman and Jenter, 2010):

$$
\begin{array}{lr}
Y=2.85+0.28 \text { Sales }-0.01 \text { Sales }^{2}+\text { IndFE } & \left(N=12,731, R^{2}=0.23\right),(1) \\
Y=1.93+0.51 \text { Assets }-0.02 \text { Assets }^{2}+\text { IndFE } & \left(N=12,740, R^{2}=0.26\right),(2)
\end{array}
$$

and

$$
Y=4.31+0.18 \text { Employees }-0.01 \text { Employees }^{2}+\operatorname{IndFE} \quad\left(N=12,662, R^{2}=0.19\right)
$$

where $Y$ is the natural logarithm of a firm's average director compensation (the sum of cash and equity compensation, averaged across the nonexecutive directors in ExecuComp), the firm characteristics are in natural logs, IndFE is two-digit SIC industry fixed effects, and $N$ is firmyears. All of the above coefficients are statistically significant at the $1 \%$ level. Our estimate of the nonexecutive director compensation is the predicted value from regression Eq. (1). If information on Sales is missing for the new firm, we use regression Eq. (2), and if both Sales and Assets are missing, we use regression Eq. (3).

For the 66 sample CEOs who become consultants or self-employed, we assign an average income of $\$ 500,000$ in 2009 dollars. This estimate is based on consulting fees observed for a few departing CEOs in our sample. For example, Andres Bande of Flag Telecom received $\$ 350,000$ in 2002, and Robert Cole of Lodgian, Inc. reveived $\$ 750,000$ in 2011. Finally, for the 170 CEOs classified as 
receiving no new employment, we assign an income of zero. To the extent that we are missing some future employment income, our estimated loss of labor market capital is biased upward for this category of CEOs.

\subsection{CEO compensation change from bankruptcy}

In this subsection, we compute the present value of the compensation change until age 65 . This calculation uses a constant discount rate of $10 \%$ for all CEOs, accounts for the time between the CEO's departure and new employment, and includes severance pay. As shown in the Table 9, $28 \%$ of the departed CEOs receive severance, with a median of $\$ 1.6$ million (three times old pay). The extant literature shows a higher rate of severance pay of $40 \%$ to $50 \%$ for CEO turnover in nondistressed firms (Almazan and Suarez, 2003; Fee and Hadlock, 2004; Yermack, 2006; Goldman and Huang, 2014). Our analysis does not include pension losses in bankruptcy. However, Sundaram and Yermack (2007) report that the median CEO of an S\&P 500 firm has a pension worth only $7 \%$ of his equity holdings.

******************** Insert Table 9 near here $* * * * * * * * * * * * * * * * * *$

Table 10 reports the median compensation change (new minus old compensation), the PV of the compensation change, and the multiple of PV to the old income. It shows the compensation change for CEOs maintaining executive employment at the restructured or another firm. For the incumbents, the median compensation and PV compensation changes are insignificantly different from zero. This result holds whether the incumbent remains with the restructured firm or departs for a new executive position. Moreover, while not shown in the table, whether the incumbent is a founder or not makes no difference for the median income change or its present value.

******************* Insert Table 10 near here $* * * * * * * * * * * * * * * * * *$

Regarding the PV multiples (Column 5), the median is insignificant for the pool of all incumbents. However, the multiple is 1.1 times old income (significant at the $5 \%$ level) for the incumbents remaining with the restructured firm. In sum, incumbents who remain in the executive labor market typically do not experience a compensation decline from bankruptcy.

The median replacement CEO experiences a significantly positive compensation change, whether 
in terms of percentage change or multiple. However, the difference in median between the incumbents and replacement CEOs is significant at the $5 \%$ level only for CEOs who depart for a new executive position (Column 5). Thus, neither incumbents nor replacement CEOs appear to suffer a labor market loss from bankruptcy conditional on maintaining executive employment.

The table also shows statistics for CEOs classified as leaving the executive labor market. As indicated by the median percent compensation change of -100 in Column 3, the typical CEO in this panel receives no new employment after departing the firm. Both incumbents and replacement CEOs typically experience significant loss of executive labor market capital. For incumbents, the median PV is $-\$ 7.2$ million, or -4.6 times old income. For replacement CEOs, it is $-\$ 5.3$ million and -5.3 times old income. The difference in PV between incumbent and replacement CEOs is statistically insignificant.

Table 10 suggests that CEOs who continue in executive employment are not tainted by the bankruptcy event. In Table 11, we further test whether, for these CEOs, a difference exists in the compensation change of incumbents and replacement CEOs and of founder and nonfounder incumbents. The dependent variables are the percent compensation change and PV compensation multiple (inferences are unchanged when measuring the dependent variable in dollar terms). We use quantile (median) regressions to alleviate potential issues with outliers and control for firm and bankruptcy characteristics.

******************** Insert Table 11 near here $* * * * * * * * * * * * * * * * * *$

The first regression in Table 11 confirms the univariate result in Panel A of Table 10. As indicated by Incumbent, the compensation change is lower for incumbent CEOs than for replacement CEOs (at the $5 \%$ level of significance). However, this difference becomes insignificant after controlling for firm characteristics in Column 2. The firm and bankruptcy characteristics themselves are largely insignificant and therefore suppressed in this table for expositional simplicity. Also, no statistically significant difference exists in the compensation change experienced by founder and nonfounder incumbents.

In sum, for CEOs maintaining executive employment, we fail to find evidence of a significant 
compensation change difference between incumbent and replacement CEOs and between founder and nonfounder incumbents. This suggests that CEO personal costs of corporate bankruptcy are largely determined by the likelihood of continuing as executive (Table 7). In addition, executives of bankrupt firms experience a loss of value of personal equity holdings in the firm.

\subsection{CEO loss of equity invested in the bankrupt firms}

In this subsection, we provide information on median share holdings (vested and unvested, not including unexercised options) of the CEOs in our sample, using the year-end values reported by the company. Fig. 2 plots the median share ownership in event time around bankruptcy filing, from year -3 through year -1 and from Emergence+1 through Emergence+3. The median dollar value of option holdings is zero over the event window and is excluded from the graph. The figure also excludes the year of bankruptcy because the length of the bankruptcy proceedings varies across firms. The figure displays the holdings of our sample CEOs as well as of industry peer CEOs in ExecuComp matched on two-digit SIC code and size. Moreover, the figure shows the holdings of the subset of incumbents in place at the bankrupt firm in year -1 .

******************** Insert Figure 2 near here $* * * * * * * * * * * * * * * * * *$

In Panel $\mathrm{A}$, in year -3 , the median CEO (all incumbents) holds $\$ 5.6$ million of equity in the sample firm. In comparison, peer CEOs own $\$ 7.0$ million in the same event year. Moving forward in event time, as the firm approaches bankruptcy, the median sample CEO's equity holding drops to $\$ 1.0$ million in year -1 and that of the matched CEO remains largely constant. Singling out the incumbents who stay with the firm through the end of year -1 or longer, the median CEO owns $\$ 10.6$ million in year -3 , which drops to $\$ 2.2$ million in year -1 . Thus, incumbents who stay until filing have typically greater initial equity holdings and, therefore, suffer greater loss of value.

As the sample firms emerge from bankruptcy and the CEOs receive new equity grants (Goyal and Wang, 2014), the median value of CEO equity holdings increases to $\$ 2.2$ million in Emergence +1 and to $\$ 4.2$ million two years later. As shown in the figure, these post-bankruptcy equity holdings for CEOs of emerging firms approach the dollar value of the matched CEOs' median share holdings. 
Turning to the percentage share ownership in Panel B, the median in year -3 is $2.0 \%$ for the total sample of incumbent CEOs and 3.0\% for the subsample of incumbents that stay through year -1. This difference is consistent with the finding in Table 6 that CEOs with relatively low equity ownership are more likely to leave voluntarily, as if equity ownership provides an incentive to stay with the firm.

Moreover, the median equity ownership declines to $1.5 \%$ in year -1 for the total CEO sample and remains relatively constant at $0.6 \%$ for the industry peers. However, for the incumbents who stay on as CEOs through year -1, the median percentage equity ownership does not decline. Instead, it increases slightly from $3.0 \%$ to $3.2 \%$ over the event period year -3 through year -1 . Because only about $15 \%$ of the incumbent CEOs receive restricted stock awards in the pre-filing years, this suggests that the median CEO does not sell out when approaching bankruptcy.

While we do not study insider trades directly, our evidence of relatively stable equity holdings by incumbent CEOs who remain with the distressed firm is consistent with Loderer and Sheehan (1989). They also report that corporate insiders do not typically reduce their equity ownership prior to Chapter 11 filing. Our evidence, however, appears to contradict Seyhun and Bradley (1997), who find significant net sales by top executives in the years surrounding bankruptcy filing. An interesting question, which goes beyond this paper, is whether our evidence reflects stronger enforcement of insider trading laws in our more recent sample period.

\section{CEO compensation prior to filing}

Table 12 provides estimates of cross-sectional determinants of the CEO compensation at the sample firm prior to Chapter 11 filing. The first two columns model the level of compensation and the last two columns model the proportion of the compensation paid in cash. We use this table to examine whether incumbents (founders and nonfounders) earn executive labor market rents relative to replacement CEOs.

******************* Insert Table 12 near here $* * * * * * * * * * * * * * * * * *$

Among the significant characteristics in Table 12, pre-filing CEO compensation increases with 
Size and Cash, both of which captures higher pay at larger firms. Also, as expected, pre-filing compensation tends to decrease with Industry distress, reflecting generally lower CEO pay in severely distressed industries (median stock return below -30\%). Moreover, pre-filing compensation is lower in firms that undertake prepackaged filings, when the proportion of the compensation that is paid in cash is also higher. A consistent interpretation is that prepacks are executed by restructuring specialists who tend to be paid less than regular CEOs and with a greater proportion of cash.

Furthermore, pre-filing compensation is decreasing in CEO age and the fraction of the compensation paid in cash is higher the older the CEO. Finally, pre-filing compensation tends to be higher in firms subsequently facing allegations of financial fraud. Some fraud allegations include a charge that the firm has overstated its income, which by itself leads to higher compensation.

The dummy variable Incumbent is positive and highly significant in Column 1. This suggests that incumbent CEOs have higher pre-filing average compensation than replacement CEOs after controlling for CEO, firm, and industry characteristics. Moreover, as shown in Column 2, this effect is present both for founder and nonfounder incumbents (the difference between these two groups is statistically insignificant, with a P-value of 0.134 ). This evidence is consistent with the existence of a rent component in the incumbents' compensation not accounted for by the other regressors in Table 12.

The median incumbent CEO who ends up moving to a new executive position does not experience a change in compensation. This suggest that the rent component in the compensation of these relatively successful incumbents is not firm-specific. CEOs who depart to another executive position prior to filing could simply be highly skilled in general relative to the incoming replacements CEOs. As to the remaining incumbents, however, the evidence is insufficient to determine whether the rent component is firm-specific, which it would have to be to reflect CEO overpayment. 


\section{Conclusion}

How large are CEO personal costs from corporate bankruptcy? Are filing CEOs punished by the executive labor market? Is CEO turnover influenced by creditor control rights? We provide some first, large-sample empirical evidence regarding these complex empirical questions. We study CEO income and wealth losses from Chapter 11 bankruptcy filing by publicly traded US firms, focusing on incumbent CEOs (in place three years prior to filing). Moreover, we identify potential effects of the incumbent being the company founder.

A major contribution of our empirical analysis is to identify executive employment after leaving the bankrupt firm, which has been largely missing in the literature on Chapter 11 bankruptcy. Cross-sectional regressions show how CEO, firm, and bankruptcy characteristics are associated with the likelihood of forced and voluntary CEO turnover, as well as the likelihood that the incumbent CEO departs to an executive position at another firm. Moreover, we estimate the present value compensation change until age 65, and we provide a perspective on the compensation contract of incumbents by comparing it with that of replacement CEOs.

CEO turnover, both forced and voluntary, is high around bankruptcy filing and, as expected, negatively associated with industry-adjusted operating performance (return on assets). Voluntary departure is positively associated with CEO age and negatively associated with CEO chairmanship and shareholdings in the distressed firm, as if high equity ownership incentivizes CEOs to stay. Forced CEO turnover is higher in the presence of fraud allegations. Founder incumbents are marginally less likely to be forced out than nonfounder incumbents, possibly because the former have more firm-specific human capital of value to the distressed firm.

We find that one-third of the incumbent CEOs maintain executive employment after bankruptcy, either at a new firm or at the restructured firm emerging from bankruptcy. The remaining twothirds of incumbents leave the executive labor market. Of those who leave, some become nonexecutive corporate directors or consultants, while others retire. As expected, the likelihood of leaving the executive labor market decreases with the firms industry-adjusted profitability.

Creditor control rights appear to influence CEO personal costs of corporate bankruptcy. As 
expected, forced turnover is higher during bankruptcy. More important, CEOs of firms receiving DIP financing are more likely to be forced out, sometimes as a consequence of the exercise of DIP financing covenants, and to leave the executive labor market. Moreover, CEOs of firms with large trade credits are less likely to be forced out and more likely to remain with the restructured firm, possibly reflecting strong economic ties as part of an efficient supply chain.

Another key finding is that incumbents who maintain executive employment experience a median estimated compensation change of zero. This result holds whether the CEO stays with the restructured firm or assumes an executive position at another firm. In other words, these executives appear to maintain their labor market capital in spite of bankruptcy. In contrast, incumbents leaving the executive labor market experience large compensation losses. The median estimated compensation loss for this group equals five times the pre-departure income (a median loss until age 65 of $\$ 7$ million).

After adjusting for CEO and firm-specific factors, and conditional on maintaining executive employment either at the restructured firm or at a new firm, we find no difference in the compensation change around bankruptcy between incumbent and replacement CEOs. Also, no difference emerges in the conditional compensation change between founder and nonfounder incumbents. In sum, CEO personal costs of corporate bankruptcy, as measured here, are primarily determined by whether or not the CEO leaves the executive labor market.

CEO equity losses prior to Chapter 11 filing are substantial. Incumbent CEOs in place at yearend prior to filing suffer a decline in median equity value of $\$ 9$ million. In the year of filing, when fiduciary restrictions most likely prevent the CEO from selling equity, there is a further median loss of $\$ 2$ million, for a total wealth loss of $\$ 11$ million. No evidence exists that the median incumbent CEO reduces his percentage stock ownership during the slide toward bankruptcy filing.

Do incumbent CEOs earn firm-specific rents prior to filing? On the one hand, we find that incumbents have significantly higher average pre-filing compensation than replacement CEOs. This effect, which is present for both founder and nonfounder incumbents, holds after controlling for CEO, firm, and industry characteristics, and it suggests the presence of a rent component in 
incumbents' pre-filing compensation. On the other hand, because incumbents who depart for new executive positions do not experience a compensation change at the new firm, these executives could be paid more than the replacement CEOs simply because they are better managers. As to the remaining departing incumbents, however, our evidence is insufficient to determine whether the rent component is specific to the bankrupt firm. 
Acharya, V. V., Bharath, S. T., Srinivasan, A., 2007. Does industry-wide distress affect defaulted firms? Evidence from creditor recoveries. Journal of Financial Economics 85, 787-821.

Adams, R., Almeida, H., Ferreira, D., 2009. Understanding the relationship between founder-CEOs and firm performance. Journal of Empirical Finance 16, 136-150.

Almazan, A., Suarez, J., 2003. Entrenchment and severance pay in optimal structures. Journal of Finance 58, 519-548.

Anderson, R. C., Reeb, D. M., 2003. Founding-family ownership and firm performance: evidence from the S\&P 500. Journal of Finance 58, 1301-1328.

Ayotte, K. M., Hotchkiss, E. S., Thorburn, K. S., 2013. Governance in financial distress and bankruptcy. In: Wright, M., Siegel, D. S., Keasey, K., Filatotchev, I. (Eds.), The Oxford Handbook of Corporate Governance. Oxford University Press, Oxford, UK, Ch. 489-512.

Ayotte, K. M., Morrison, E. R., 2009. Creditor control and conflict in Chapter 11. Journal of Legal Analysis 1, 511-551.

Bates, T. W., Kahle, K. M., Stulz, R. M., 2009. Why do US firms hold so much more cash than they used to? Journal of Finance 64, 1985-2021.

Berk, J. B., Stanton, R., Zechner, J., 2010. Human capital, bankruptcy, and capital structure. Journal of Finance 65, 891-926.

Chemmanur, T. J., Cheng, Y., Zhang, T., 2013. Human capital, capital structure, and employee pay. Journal of Financial Economics 110, 478-502.

Core, J., Guay, W., 1999. The use of equity grants to manage optimal equity incentive levels. Journal of Financial Economics 28, 151-184.

Core, J. E., Holthausen, R. W., Larker, D. F., 1999. Corporate governance, chief executive officer compensation, and firm performance. Journal of Financial Economics 23, 1004-1050.

Dahiya, S., John, K., Puri, M., Ramirez, G., 2003. Debtor-in-possession financing and bankruptcy resolution: empirical evidence. Journal of Financial Economics 69, 259-280.

Denis, D. J., Denis, D. K., 1995. Causes of financial distress following leveraged recapitalizations. Journal of Financial Economics 37, 129-157.

Desai, H., Hogan, C. E., Wilkins, M. S., 2006. The reputational penalty for aggressive accounting: earnings restatements and management turnover. Accounting Review 81, 83-112.

Eckbo, B. E., Thorburn, K. S., 2003. Control benefits and CEO discipline in automatic bankruptcy auctions. Journal of Financial Economics 69, 227-258.

Eisdorfer, A., 2008. Empirical evidence of risk shifting in financially distressed firms. Journal of Finance 68, 609-637. 
Fahlenbrach, R., 2009. Founder-CEOs, investment decisions, and stock market performance. Journal of Financial and Quantitative Analysis 44, 439-466.

Fee, C. E., Hadlock, C. J., 2003. Raids, rewards, and reputations in the market for managerial talent. Review of Financial Studies 16, 1315-1357.

Fee, C. E., Hadlock, C. J., 2004. Management turnover across the corporate hierarchy. Journal of Accounting and Economics 37, 3-38.

Frydman, C., Jenter, D., 2010. CEO compensation. Annual Review of Financial Economics 2, 75-102.

Gao, H., Lemmon, M., Li, K., 2011. A comparison of CEO pay in public and private US firms. Unpublished working paper. University of British Columbia, British Columbia, Canada.

Gao, H., Li, K., 2015. A comparison of CEO pay-performance sensitivity in privately-held and public firms. Journal of Corporate Finance 35, 370-388.

Gilson, S. C., 1989. Management turnover and financial distress. Journal of Financial Economics 25, 241-262.

Gilson, S. C., Vetsuypens, M. R., 1993. CEO compensation in financially distressed firms: an empirical analysis. Journal of Finance 48, 425-458.

Goldman, E. M., Huang, P. P., 2014. Contractual versus actual separation pay following CEO departure. Management Science 61, 1108-1120.

Goyal, V., Wang, W., 2014. Provision of management incentives in bankrupt firms. Unpublished working paper. Queen's University, Kingston, Ontario, Canada.

Harford, J., Li, K., 2007. Decoupling CEO wealth and firm performance: the case of acquiring CEOs. Journal of Finance 62, 917-949.

Hertzel, M., Li, Z., Officer, M., Rodgers, K., 2008. Inter-firm linkages and the wealth effects of financial distress along the supply chain. Journal of Financial Economics 87, 374-387.

Hotchkiss, E. S., 1995. Post-bankruptcy performance and management turnover. Journal of Finance $50,3-21$.

Hotchkiss, E. S., John, K., Mooradian, R., Thorburn, K. S., 2008. Bankruptcy and the resolution of financial distress. In: Eckbo, B. E. (Ed.), Handbook of Corporate Finance: Empirical Corporate Finance. Vol. 2. Handbook in Finance Series. Elsevier/North-Holland, Amsterdam, 235-289.

Huson, M. R., Malatesta, P. H., Parrino, R., 2004. Managerial succession and firm performance. Journal of Financial Economics 74, 237-275.

Huson, M. R., Parrino, R., Starks, L., 2001. Internal monitoring mechanism and CEO turnover: a long-term perspective. Journal of Finance 56, 2265-2297. 
Jensen, M. C., Meckling, W., 1976. Theory of the firm: managerial behavior, agency costs, and capital structure. Journal of Financial Economics 3, 305-360.

Jenter, D., Kanaan, F., 2014. CEO turnover and relative performance evaluation. Journal of Finance 70, 2155-2184.

Jiang, W., Li, K., Wang, W., 2012. Hedge funds and Chapter 11. Journal of Finance 76, 513-560.

Kaplan, S. N., Rau, J., 2010. Wall Street and Main Street: what contributes to the rise in the highest incomes? Review of Financial Studies 23, 1004-1050.

Kolay, M., Lemmon, M. L., Tashjian, E., 2015. Spreading the misery: sources of bankruptcy spillover in the supply chain. Journal of Financial and Quantitative Analysis, forthcoming.

Li, Y., Lu, R., Srinivasan, A., 2013. Relationship bank behavior during borrower distress. Unpublished working paper. National University of Singapore, Singapore.

Loderer, C. F., Sheehan, D. P., 1989. Corporate bankruptcy and managers' self-serving behavior. Journal of Finance 49 (4), 1059-1075.

Murphy, K. J., 1999. Executive compensation. In: Ashenfelter, O., Card, D. (Eds.), Handbook of Labor Economics. Vol. 3b. Elsevier/North Holland, Amsterdam, 2485-2563.

Opler, T. C., Titman, S., 1994. Financial distress and corporate performance. Journal of Finance 49, 1015-1040.

Parrino, R., 1997. CEO turnover and outside succession: a cross-sectional analysis. Journal of Financial Economics 46, 165-197.

Seyhun, H. N., Bradley, M., 1997. Corporate bankruptcy and insider trading. Journal of Business 70, 189-216.

Skeel, D. A., 2003. Creditors' ball: the 'new' new corporate governance in Chapter 11. University of Pennsylvania Law Review 152, 917-951.

Strebulaev, I. A., Yang, B., 2013. The mystery of zero-leverage firms. Journal of Financial Economics 109, 1-23.

Sundaram, R. K., Yermack, D., 2007. Pay me later: inside debt and its role in managerial compensation. Journal of Finance 62, 1551-1588.

Tashjian, E., Lease, R., McConnell, J., 1996. Prepacks: an empirical analysis of prepackaged bankruptcies. Journal of Financial Economics 40, 135-162.

Thorburn, K. S., 2000. Bankruptcy auctions: costs, debt recovery, and firm survival. Journal of Financial Economics 58, 337-368.

Warner, J. B., Watts, R. L., Wruck, K. H., 1988. Stock prices and top management changes. Journal of Financial Economics 20, 461-492. 
Weisbach, M. S., 1988. Outside directors and CEO turnover. Journal of Financial Economics 20, 431-460.

Yermack, D., 2006. Golden handshakes: separation pay for retired and dismissed CEOs. Journal of Accounting and Economics 41, 237-256. 


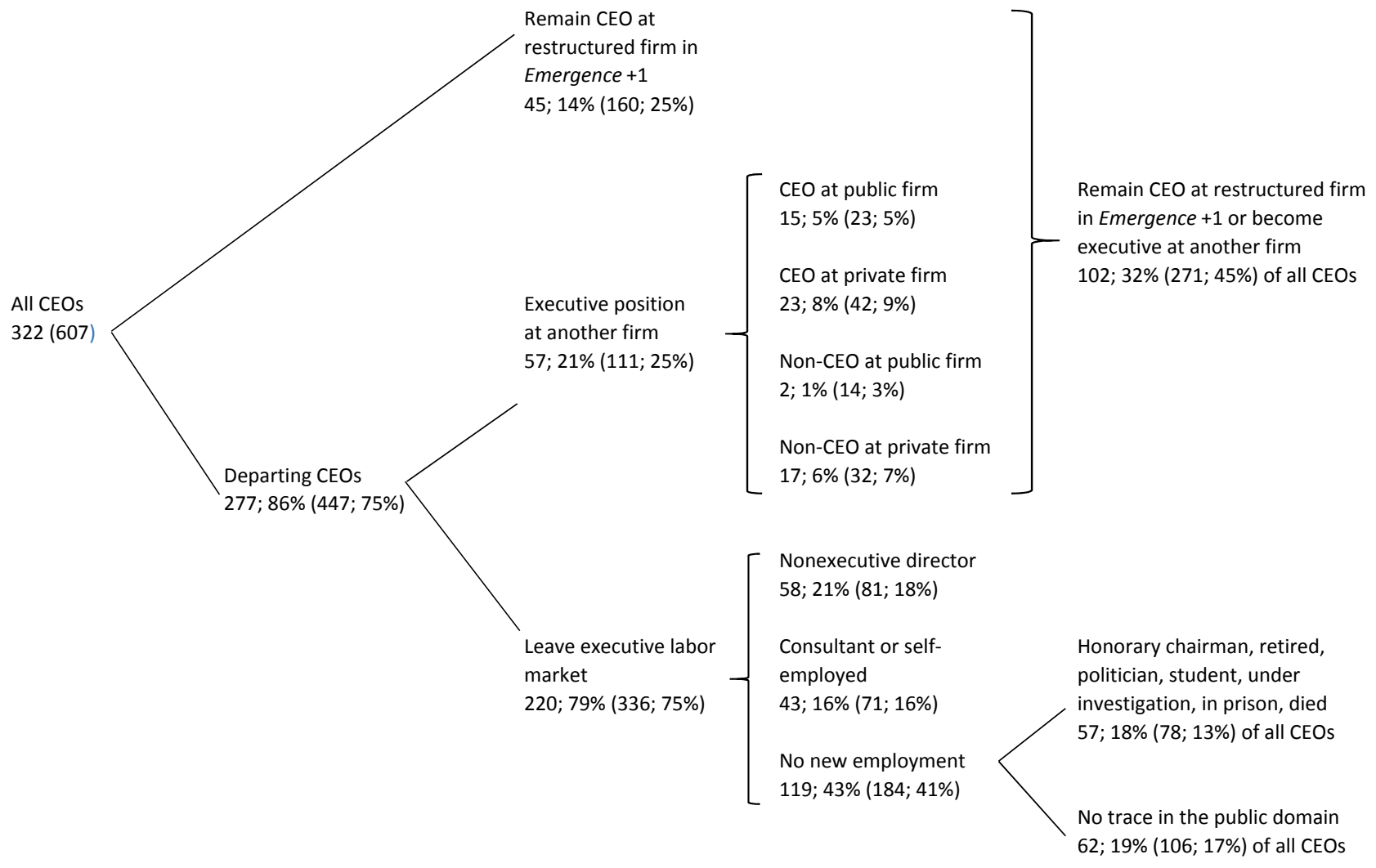

Fig. 1. Chief executive officer (CEO) new employment around bankruptcy. The figure lists the number and percent of CEOs across different new employment categories for the 322 incumbent CEOs (in place at the end of year -3 ) and, in parentheses, the total sample of 607 incumbent and replacement CEOs. The departing CEOs leave their position before year-end Emergence+1. Replacement CEOs hired in year Emergence +1 are excluded. The information is from industry manuals, proxy filings, press releases, and social media. The sample contains 322 large public US firms filing for Chapter 11 in the 1996 to 2007 period. 


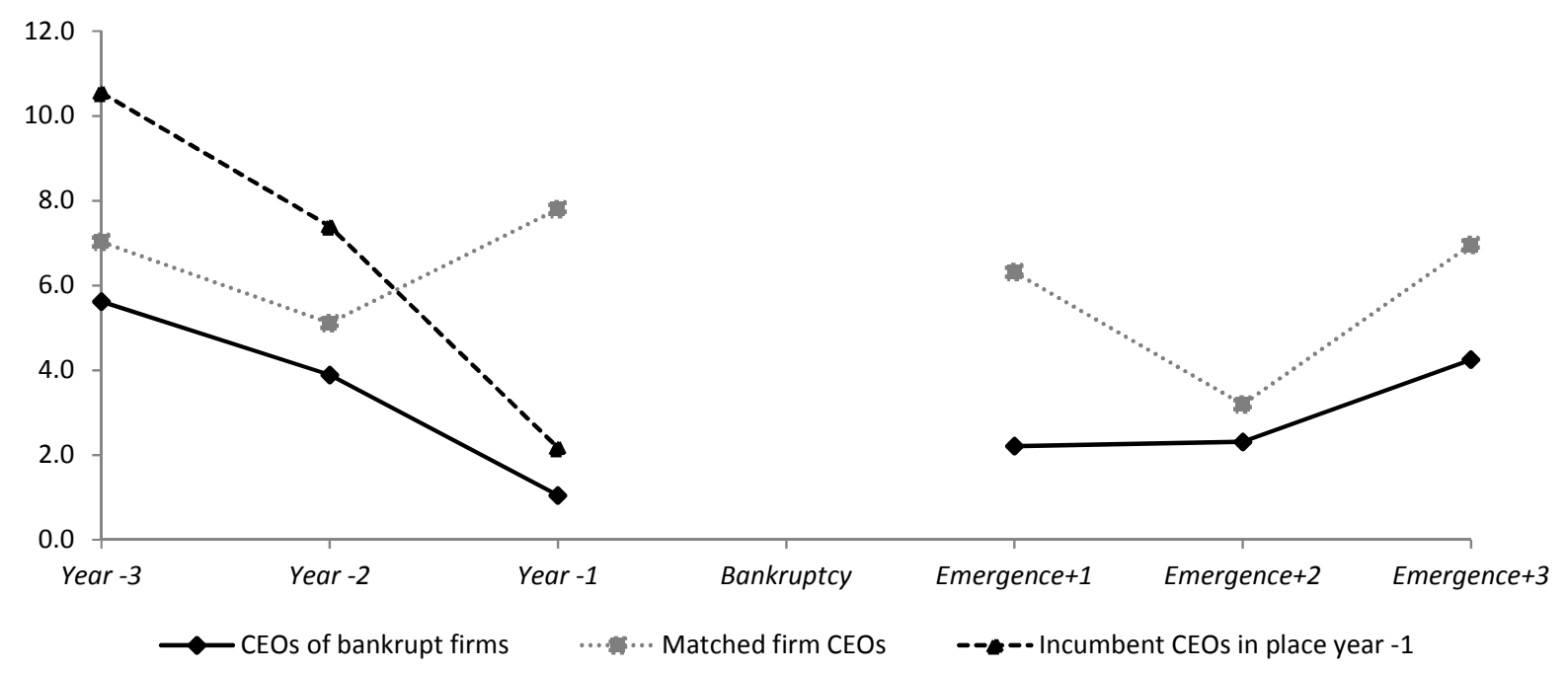

Panel B: Median percent CEO share ownership

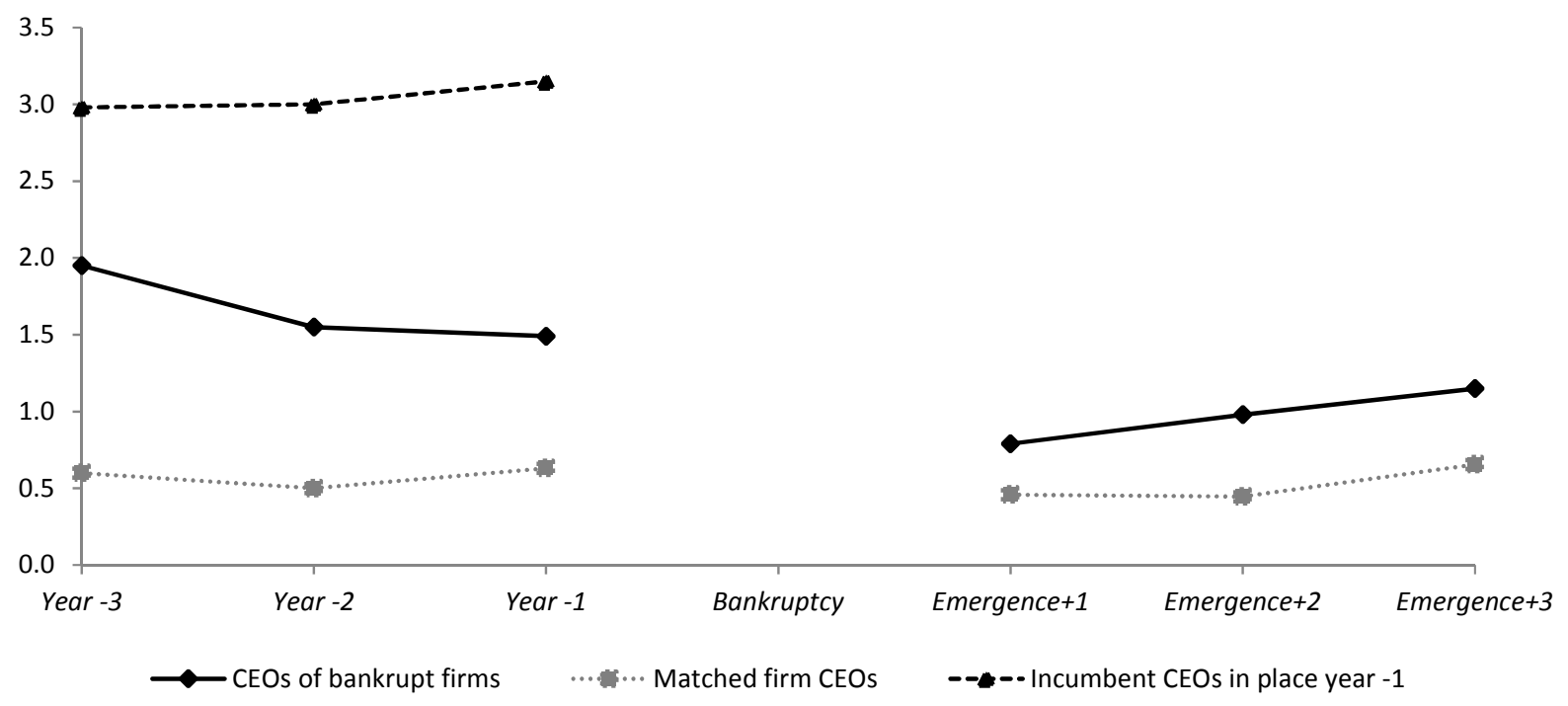

Fig. 2. Median chief executive officer (CEO) share ownership around bankruptcy filing. The figure shows the median CEO share ownership in the sample firm in event time prior to bankruptcy filing (event year 0) and after emergence from bankruptcy. In the figure, Bankruptcy includes all years from filing through emergence. Panel A shows the value in millions of dollars, and Panel B shows the percent of shares outstanding. The figure plots the median share ownership for three groups: all sample CEOs, the subset of incumbent CEOs who remain at the end of year -1, and CEOs of peer firms in ExecuComp matched on two-digit standard industry classification (SIC) industry and sales (if no ExecuComp firm in the two-digit SIC industry has sales within 30\%, the match uses one-digit SIC industry and sales). Data sources are ExecuComp, 10Ks, and proxy filings. The sample contains 313 large public US firms filing for Chapter 11 in the 1996 to 2007 period. After emergence, the sample is restricted to 113 firms that emerge from bankruptcy as public firms. 


\section{Table 1}

Annual distribution of sample bankruptcy filings and firm characteristics.

The table shows mean and median values of sales and book value of total assets in the year prior to bankruptcy filing (millions of constant 2009 US dollars). A prepack is a prepackaged bankruptcy filing, in which the firm files a plan of reorganization jointly with its bankruptcy petition. The outcome Emerge describes a firm that emerges from Chapter 11 as an independent restructured company with a reorganization plan confirmed by the bankruptcy court. The outcome Liquidate (Acquired) describes firms that were liquidated piecemeal (acquired as a going concern) in Chapter 11. Duration is the number of months from bankruptcy filing to any of the three outcomes. Forty-eight percent of the cases are resolved within 12 months and $78 \%$ within 24 months. Prepacks have an average duration of six month (median four months). The sample contains 322 large public US firms filing for Chapter 11 from 1996 to 2007.

\begin{tabular}{|c|c|c|c|c|c|c|c|c|c|c|c|}
\hline \multicolumn{2}{|l|}{$\overline{\text { Filing }}$} & \multicolumn{2}{|c|}{ Sales (dollars) } & \multicolumn{2}{|c|}{ Total assets (dollars) } & \multicolumn{2}{|c|}{ Duration } & \multirow{2}{*}{$\begin{array}{l}\text { Percent } \\
\text { prepacks }\end{array}$} & \multicolumn{3}{|c|}{ Outcome (percent) } \\
\hline year & $N$ & Mean & Median & Mean & Median & Mean & Median & & Emerge & Liquidate & Acquired \\
\hline 1996 & 7 & 1,972 & 832 & 829 & 593 & 8.5 & 4.5 & 43 & 43 & 43 & 14 \\
\hline 1997 & 13 & 1,665 & 641 & 1,274 & 464 & 23.1 & 17.5 & 31 & 85 & 15 & 0 \\
\hline 1998 & 25 & 728 & 389 & 752 & 503 & 19.3 & 14.1 & 28 & 68 & 24 & 8 \\
\hline 1999 & 32 & 1,320 & 641 & 1,655 & 842 & 16.3 & 9.4 & 38 & 59 & 34 & 6 \\
\hline 2000 & 51 & 1,448 & 779 & 1,481 & 633 & 22.9 & 19.6 & 22 & 57 & 31 & 12 \\
\hline 2001 & 58 & 4,051 & 805 & 4,164 & 1,346 & 17.8 & 13.1 & 17 & 53 & 36 & 10 \\
\hline 2002 & 54 & 3,846 & 1,009 & 7,326 & 1.195 & 13.2 & 8.4 & 46 & 63 & 19 & 18 \\
\hline 2003 & 33 & 1,151 & 741 & 2,180 & 778 & 15.0 & 9.7 & 30 & 73 & 18 & 9 \\
\hline 2004 & 16 & 1,381 & 561 & 1,585 & 766 & 12.2 & 10.2 & 38 & 88 & 13 & 0 \\
\hline 2005 & 17 & 5,854 & 1,017 & 9,194 & 770 & 17.7 & 16.7 & 12 & 71 & 18 & 12 \\
\hline 2006 & 7 & 2,244 & 1,179 & 1,859 & 497 & 9.2 & 5.5 & 71 & 100 & 0 & 0 \\
\hline 2007 & 9 & 777 & 414 & 4,178 & 705 & 10.2 & 11.6 & 33 & 44 & 56 & 0 \\
\hline All & 322 & 2,468 & 772 & 3,450 & 847 & 16.9 & 12.8 & 30 & 64 & 26 & 10 \\
\hline
\end{tabular}




\section{Table 2}

Definitions of variables used in the analysis of chief executive officer (CEO) personal costs of corporate bankruptcy.

The sample contains 642 CEOs of 322 large public US firms filing for Chapter 11 in the 1996 to 2007 period. Year 0 denotes the year of bankruptcy filing. BRD is Bankruptcy Research Database, BD is BankruptcyData.com, Bcy plans is bankruptcy plans, CapIQ is Standard \& Poor's (S\&P) Capital IQ, and proxies is proxy statements. The sources for bankruptcy plans are BankruptcyData.com, 8Ks, and US bankruptcy courts. The 10Ks, $8 \mathrm{Ks}$, and proxy statements are from EDGAR (Electronic Data Gathering, Analysis, and Retrieval system), and the 13Fs are from Thomson Reuters Ownership Databases.

Variable name Definition $\quad$ Source

CEO characteristics

Age

Chairman

Share ownership

Incumbent

Founder incumbent

Nonfounder incumbent

Replacement

\section{$\mathrm{CEO}$ age in years.}

Dummy indicating that the CEO is chairman of the board.

Percent of the sample firm's common shares owned by the CEO.

CEO in place at end of fiscal year -3 relative to year of filing.

Dummy indicating that the incumbent CEO is the company founder.

Dummy indicating that the incumbent CEO is not the company founder.

CEO appointed at the sample firm in year -2 to Emergence+1.

Dummy indicating that the departure is performance-related or follows pressure by the board, shareholders, or creditors

Weakly forced turnover

Voluntary turnover

CEO compensation variables Cash compensation

Equity grants

Total compensation

Proportion cash pay

Compensation change

PV compensation change

Contractual severance
Forced turnover plus cases in which the CEO is under 60 years old and leaves for

Dummy indicating that the departure is not forced.

Sum of salary, bonus, long-term incentive plans, and other cash compensation.

Total value of restricted stock and options granted.

Sum of cash compensation and equity grants.

Fraction of the total compensation paid in cash.

Difference between the old and new compensation. The old compensation at the sample firm is measured in year -3 or, if missing, year -2 for incumbent CEOs and the first two years of employment for replacement CEOs. Estimation of the new compensation is explained in Table 8.

Present value of the compensation change through age 65 , discounted at a $10 \%$ rate, and adjusted for severance and time to new employment.

Separation pay based on contract. personal reasons or to pursue other interests.
ExecuComp, 10Ks, proxies

ExecuComp, 10Ks, proxies ExecuComp, 10Ks, proxies 10Ks, proxies, Factiva $10 \mathrm{Ks}$, proxies, Factiva 10Ks, proxies, Factiva 10Ks, proxies, Factiva 10Ks, proxies, Factiva

10Ks, proxies, Factiva

10Ks, proxies, Factiva

ExecuComp, 10Ks, proxies ExecuComp, 10Ks, proxies ExecuComp, 10Ks, proxies ExecuComp, 10Ks, proxies

10Ks, proxies, Factiva 


\section{Discretional severance}

Severance

Sample firm characteristics

Size

Industry-adjusted ROA

Industry-adjusted leverage

Cash

Tangibility

Industry distress

Institutional ownership

\section{Bond debt}

Trade credit

Bankruptcy characteristics

Emergence

During bankruptcy

Prepack

DIP financing

Fraud
Discretional separation pay including lump-sum cash pay, loan forgiveness, adjustment to pension benefits, consulting contract, and equity incentives.

Sum of contractual and discretional severance.

Logarithm of total sales in millions of 2009 dollars.

Firm return on assets (ROA) [ratio of earnings before interest, taxes, depreciation, and amortization (EBITDA) to book assets] minus the median ROA of Compustat firms in the two-digit standard industrial classification (SIC) industry.

Firm leverage (defined as the ratio of total liabilities to book assets) net of the median leverage for Compustat firms in the two-digit SIC industry.

Ratio of cash and short-term investment to book assets.

Ratio of net plant, property, and equipment (PP\&E) to book assets.

Dummy indicating that the median stock return in the two-digit SIC industry is less than $-30 \%$ in that year.

Dummy indicating that institutional investors own at least $20 \%$ of the firm's shares.

Dummy indicating that the face value of bonds is at least two-thirds of the firm's total liabilities.

Dummy indicating that the total liabilities net of bank loans and bonds are at least two-thirds of the firm's total liabilities.

Confirmation of the reorganization plan by the bankruptcy court, after which the firm emerges as an independent company.

Dummy indicating the year of filing (event year 0) through the year of emergence (Emergence).

Dummy indicating that a reorganization plan is filed jointly with the bankruptcy petition.

Dummy indicating that the firm receives debtor-in-possession (DIP) financing.
10Ks, proxies, Factiva

$10 \mathrm{Ks}$, proxies, Factiva

Compustat, 10Ks

Compustat, $10 \mathrm{Ks}$

Compustat, $10 \mathrm{Ks}$

Compustat, $10 \mathrm{Ks}$

Compustat, 10Ks

Compustat

$13 \mathrm{Fs}$

Bcy plans, Compustat, CapIQ

Bcy plans, Compustat, CapIQ

BRD, BD, Bcy plans

BRD, BD, Bcy plans

BRD, BD, Bcy plans

BRD, BD, Bcy plans, Factiva 
Table 3

Summary statistics for variables used in the cross-sectional analysis.

The statistics are measured at the end of year -3 (end of year -2 for three firms that went public that year). All variables are defined in Table 2. The sample contains 322 large public US firms filing for Chapter 11 from 1996 to 2007.

\begin{tabular}{|c|c|c|c|c|c|c|}
\hline & $N$ & Mean & Standard deviation & Minimum & Median & Maximum \\
\hline \multicolumn{7}{|l|}{ Incumbent CEOs } \\
\hline Age & 317 & 52.6 & 8.7 & 31 & 53 & 83 \\
\hline Chairman & 322 & 0.61 & 0.49 & 0 & 1 & 1 \\
\hline Share ownership & 268 & 7.1 & 12.2 & 0.0 & 1.9 & 88.5 \\
\hline Founder incumbent & 322 & 0.18 & 0.38 & 0 & 0 & 1 \\
\hline \multicolumn{7}{|l|}{ Founder incumbents } \\
\hline Age & 57 & 50.4 & 10.6 & 31 & 51 & 83 \\
\hline Chairman & 58 & 0.74 & 0.44 & 0 & 1 & 1 \\
\hline Share ownership & 49 & 14.3 & 15.3 & 0.0 & 9.5 & 72.0 \\
\hline \multicolumn{7}{|l|}{ Nonfounder incumbents } \\
\hline Age & 260 & 53.0 & 8.1 & 33 & 53 & 79 \\
\hline Chairman & 264 & 0.58 & 0.49 & 0 & 1 & 1 \\
\hline Share ownership & 219 & 5.4 & 10.8 & 0.0 & 1.3 & 88.5 \\
\hline \multicolumn{7}{|l|}{ CEO compensation variables } \\
\hline Cash compensation & 294 & 1,451 & 2,270 & 0 & 831 & 24,670 \\
\hline Equity grants & 294 & 4,246 & 25,994 & 0 & 220 & 432,703 \\
\hline Total compensation & 294 & 5,697 & 27,093 & 0 & 1,409 & 447,467 \\
\hline Proportion cash pay & 294 & 0.67 & 0.35 & 0 & 0.76 & 1 \\
\hline \multicolumn{7}{|l|}{ Sample firm characteristics } \\
\hline Size & 294 & 6.49 & 1.72 & -0.36 & 6.63 & 10.77 \\
\hline Industry-adjusted ROA & 293 & -0.03 & 0.11 & -0.69 & -0.02 & 0.24 \\
\hline Industry-adjusted leverage & 295 & 0.23 & 0.31 & 0.57 & 0.28 & 2.67 \\
\hline Cash & 295 & 0.10 & 0.14 & 0.00 & 0.04 & 0.70 \\
\hline Tangibility & 294 & 0.36 & 0.23 & 0.00 & 0.34 & 0.89 \\
\hline Industry distress & 322 & 0.07 & 0.25 & 0 & 0 & 1 \\
\hline Institutional ownership & 322 & 0.45 & 0.50 & 0 & 0 & 1 \\
\hline Bond debt & 279 & 0.16 & 0.37 & 0 & 0 & 1 \\
\hline Trade credit & 280 & 0.18 & 0.39 & 0 & 0 & 1 \\
\hline \multicolumn{7}{|l|}{ Bankruptcy characteristics } \\
\hline Prepack & 322 & 0.30 & 0.46 & 0 & 0 & 1 \\
\hline Fraud & 322 & 0.06 & 0.23 & 0 & 0 & 1 \\
\hline DIP financing & 322 & 0.69 & 0.46 & 0 & 1 & 1 \\
\hline
\end{tabular}




\section{Table 4}

Chief executive officer (CEO) departures and replacements around bankruptcy filing.

The table shows the number of sample firms, incumbent CEOs, and CEOs who enter and leave the sample around bankruptcy filing (year 0). The sample contains 322 large public US firms filing for Chapter 11 from 1996 to 2007, with a total of 642 unique CEOs. A CEO enters the sample by being appointed CEO and exits by leaving the CEO position at the sample firm. There are 322 incumbent CEOs (in place at the end of year -3 , of which 58 are company founders) and 320 replacement CEOs. Of the replacement CEOs, 126 are internally promoted. Media describe 68 of the 194 replacement CEOs hired externally as restructuring specialists. Before bankruptcy, three firms went public in year -2. During bankruptcy, of the 322 firms, 84 emerge in year 0, 70 in Filing $+1,37$ in Filing +2 , and 14 in Filing +3 through Filing +8 , for a total of 205 firms that emerge from bankruptcy as a stand-alone restructured company. In addition, 59 firms are liquidated or acquired in year Filing +1 , 39 in year Filing +2 , and 19 in Filing +3 through Filing +8 , for a total of 118 liquidated or acquired firms. There are a total of 62 firm-years for the 33 firms in the period Filing +3 through Filing +8 . Information is missing for 15 replacement CEOs in year Emergence+1.

\begin{tabular}{|c|c|c|c|c|c|c|}
\hline \multirow[b]{2}{*}{ Event year } & \multirow[b]{2}{*}{$\begin{array}{l}\text { Sample } \\
\text { firms } \\
(1)\end{array}$} & \multirow[b]{2}{*}{$\begin{array}{l}\text { Incumbent } \\
\text { CEOs } \\
(2)\end{array}$} & \multirow[b]{2}{*}{$\begin{array}{c}\text { Replacement } \\
\text { CEOs } \\
(3) \\
\end{array}$} & \multicolumn{3}{|c|}{ CEOs who depart } \\
\hline & & & & $\begin{array}{l}\text { All } \\
(4)\end{array}$ & $\begin{array}{c}\text { Incumbent } \\
\text { CEOs } \\
(5)\end{array}$ & $\begin{array}{c}\text { Replacement } \\
\text { CEOs } \\
(6)\end{array}$ \\
\hline \multicolumn{7}{|l|}{ Before bankruptcy } \\
\hline-3 & 319 & 322 & & & & \\
\hline-2 & 322 & 262 & 60 & 60 & 60 & 0 \\
\hline-1 & 322 & 193 & 83 & 83 & 69 & 14 \\
\hline Subtotal before bankruptcy & & & 143 & 143 & 129 & 14 \\
\hline \multicolumn{7}{|l|}{ During bankruptcy } \\
\hline Filing (year 0) & 322 & 138 & 98 & 98 & 55 & 43 \\
\hline Filing +1 & 238 & 99 & 33 & 91 & 39 & 52 \\
\hline Filing +2 & 109 & 70 & 12 & 50 & 29 & 21 \\
\hline Filing +3 through Filing +8 & 33 & 4 & 64 & 20 & 6 & 14 \\
\hline Subtotal during bankruptcy & & & 147 & 259 & 129 & 130 \\
\hline \multicolumn{7}{|l|}{ After emergence } \\
\hline Emergence +1 & 205 & 45 & 30 & 45 & 19 & 26 \\
\hline Total & & & 320 & 447 & 277 & 170 \\
\hline
\end{tabular}


Table 5

Stated reasons for chief executive officer (CEO) turnover around bankruptcy filing.

The table shows reasons for CEO turnover for the 447 CEOs who depart during the event period $(-2$, Emergence+1) and were hired prior to Emergence+1. The reasons are as reported in news and company press releases. Forced turnover includes performance-related reasons and departures due to pressure from the board, shareholders, and creditors. Weakly forced turnover also includes cases in which the CEO is under 60 years old and resigns for personal reasons or to pursue other interests. The P-value shows the significance of the difference in the fraction of turnover between incumbent and replacement CEOs. The 447 CEOs represent 277 firms, from the total sample of 642 CEOs and 322 large public US firms filing for Chapter 11 in 1996-2007. Miscellaneous reasons include end of transition period, finish restructuring the company, return to own company, and investigation or inquiry by a special committee.

\begin{tabular}{|c|c|c|c|c|c|c|c|}
\hline \multirow[b]{2}{*}{ Reason for CEO departure } & \multicolumn{2}{|c|}{ All CEOs } & \multicolumn{2}{|c|}{ Incumbent CEOs } & \multicolumn{2}{|c|}{ Replacement CEOs } & \multirow{2}{*}{$\begin{array}{c}\text { P-value } \\
\text { of difference }\end{array}$} \\
\hline & $N$ & Percent & $N$ & Percent & $N$ & Percent & \\
\hline Personal reasons & 93 & 21 & 62 & 22 & 31 & 18 & $(0.295)$ \\
\hline Pursue other interests & 50 & 11 & 26 & 9 & 24 & 14 & $(0.124)$ \\
\hline Retirement or normal succession & 68 & 15 & 57 & 21 & 11 & 6 & $(0.000)$ \\
\hline Death or illness & 2 & 0 & 1 & 0 & 1 & 1 & $(0.727)$ \\
\hline Performance-related & 16 & 3 & 13 & 5 & 3 & 2 & $(0.106)$ \\
\hline $\begin{array}{l}\text { Pressured by the board, shareholders, } \\
\text { and creditors }\end{array}$ & 63 & 14 & 45 & 16 & 18 & 10 & $(0.000)$ \\
\hline Liquidation or acquisition & 84 & 19 & 41 & 15 & 43 & 25 & $(0.006)$ \\
\hline Miscellaneous & 29 & 6 & 8 & 3 & 21 & 12 & $(0.000)$ \\
\hline No reason given & 42 & 9 & 24 & 9 & 18 & 11 & $(0.400)$ \\
\hline Total & 447 & 100 & 277 & 100 & 170 & 100 & \\
\hline Forced turnover & 79 & 18 & 58 & 21 & 21 & 12 & $(0.021)$ \\
\hline Weakly forced turnover & 198 & 44 & 131 & 47 & 67 & 39 & $(0.104)$ \\
\hline
\end{tabular}


Table 6

Determinants of the probabilities of forced and voluntary turnover around bankruptcy.

The table shows coefficient estimates from multinomial logit regressions for the probabilities of chief executive officer (CEO) turnover over the event period (-2, Emergence+1), in firms filing for Chapter 11 in 1996-2007. The dependent variable has three outcomes: voluntary turnover, forced turnover, and no turnover (the baseline outcome). Included but not reported are Fama and French 12 industry dummies and the regression constant term. The sample contains 1,187 firm-years for 314 unique firms, of which 829 firm-years represent non-prepack filings. Standard errors are in square brackets. ${ }^{* * *},{ }^{* *}$, and ${ }^{*}$ denote significance at the $1 \%, 5 \%$, and $10 \%$ level, respectively. The P-values in parentheses are from a $\chi^{2}$ test for the difference in the coefficients for Founder incumbent and Nonfounder incumbent. All variables are defined in Table 2.

\begin{tabular}{|c|c|c|c|c|c|c|}
\hline \multirow[b]{2}{*}{ Variable } & \multicolumn{2}{|c|}{$\begin{array}{l}\text { Full sample } \\
\text { (Model 1) }\end{array}$} & \multicolumn{2}{|c|}{$\begin{array}{l}\text { Full sample } \\
\text { (Model 2) }\end{array}$} & \multicolumn{2}{|c|}{$\begin{array}{c}\text { Non-prepack filings only } \\
\text { (Model 3) }\end{array}$} \\
\hline & Voluntary & Forced & Voluntary & Forced & Voluntary & Forced \\
\hline \multicolumn{7}{|l|}{ CEO characteristics } \\
\hline \multirow[t]{2}{*}{ Age } & $0.037^{* * *}$ & 0.002 & $0.036^{* * *}$ & -0.000 & $0.041^{* * *}$ & -0.011 \\
\hline & {$[0.011]$} & {$[0.018]$} & {$[0.011]$} & {$[0.019]$} & {$[0.013]$} & {$[0.024]$} \\
\hline \multirow[t]{2}{*}{ Chairman } & $-0.468^{* * *}$ & 0.025 & $-0.459^{* * *}$ & 0.070 & $-0.463^{* *}$ & -0.207 \\
\hline & {$[0.167]$} & {$[0.316]$} & {$[0.167]$} & {$[0.320]$} & {$[0.212]$} & {$[0.377]$} \\
\hline \multirow[t]{2}{*}{ Share ownership } & $-0.028^{* * *}$ & 0.002 & $-0.026^{* * *}$ & 0.006 & $-0.030^{* *}$ & 0.007 \\
\hline & {$[0.010]$} & {$[0.010]$} & {$[0.010]$} & {$[0.010]$} & {$[0.012]$} & {$[0.012]$} \\
\hline \multirow[t]{2}{*}{ Incumbent } & $0.318^{*}$ & $1.192^{* * *}$ & & & & \\
\hline & {$[0.186]$} & {$[0.353]$} & & & & \\
\hline \multirow[t]{2}{*}{ Founder incumbent } & & & 0.119 & 0.386 & -0.070 & 0.171 \\
\hline & & & {$[0.287]$} & {$[0.559]$} & {$[0.380]$} & {$[0.688]$} \\
\hline \multirow[t]{2}{*}{ Nonfounder incumbent } & & & $0.359^{*}$ & $1.335^{* * *}$ & 0.401 & $1.373^{* * *}$ \\
\hline & & & {$[0.191]$} & {$[0.359]$} & {$[0.245]$} & {$[0.429]$} \\
\hline \multicolumn{7}{|l|}{ Firm characteristics } \\
\hline \multirow[t]{2}{*}{ Size } & -0.025 & $0.272^{* *}$ & -0.026 & $0.273^{* *}$ & -0.008 & $0.230^{*}$ \\
\hline & {$[0.063]$} & {$[0.106]$} & {$[0.063]$} & {$[0.106]$} & {$[0.076]$} & {$[0.119]$} \\
\hline \multirow[t]{2}{*}{ Industry-adjusted ROA } & $-1.830^{* * *}$ & $-2.629^{* *}$ & $-1.849^{* * *}$ & $-2.658^{* *}$ & $-1.759^{*}$ & $-3.022^{*}$ \\
\hline & {$[0.677]$} & {$[1.126]$} & {$[0.678]$} & {$[1.137]$} & {$[0.929]$} & {$[1.620]$} \\
\hline \multirow[t]{2}{*}{ Industry-adjusted leverage } & 0.075 & $0.616^{*}$ & 0.069 & $0.597^{*}$ & -0.042 & 0.666 \\
\hline & {$[0.183]$} & {$[0.319]$} & {$[0.183]$} & {$[0.321]$} & {$[0.230]$} & {$[0.419]$} \\
\hline \multirow[t]{2}{*}{ Cash } & -1.147 & 0.507 & -1.108 & 0.530 & -1.042 & -0.747 \\
\hline & {$[0.852]$} & {$[1.438]$} & {$[0.852]$} & {$[1.451]$} & {$[1.046]$} & {$[1.798]$} \\
\hline \multirow[t]{2}{*}{ Tangibility } & -0.011 & -0.514 & 0.021 & -0.348 & 0.102 & 0.499 \\
\hline & {$[0.401]$} & {$[0.802]$} & {$[0.403]$} & {$[0.813]$} & {$[0.561]$} & {$[1.078]$} \\
\hline \multirow[t]{2}{*}{ Industry distress } & -0.207 & -0.134 & -0.215 & -0.142 & -0.119 & -0.411 \\
\hline & {$[0.168]$} & {$[0.300]$} & {$[0.169]$} & {$[0.300]$} & {$[0.206]$} & {$[0.364]$} \\
\hline \multirow[t]{2}{*}{ Institutional ownership } & -0.207 & -0.134 & -0.215 & -0.142 & -0.119 & -0.411 \\
\hline & {$[0.168]$} & {$[0.300]$} & {$[0.169]$} & {$[0.300]$} & {$[0.206]$} & {$[0.364]$} \\
\hline \multirow[t]{2}{*}{ Bond debt } & 0.179 & 0.100 & 0.161 & 0.064 & 0.063 & -0.519 \\
\hline & {$[0.228]$} & {$[0.414]$} & {$[0.228]$} & {$[0.419]$} & {$[0.314]$} & {$[0.558]$} \\
\hline \multirow[t]{2}{*}{ Trade credit } & -0.056 & $-0.815^{* *}$ & -0.062 & $-0.836^{* *}$ & -0.211 & $-1.064^{* *}$ \\
\hline & {$[0.202]$} & {$[0.378]$} & {$[0.202]$} & {$[0.378]$} & {$[0.246]$} & {$[0.456]$} \\
\hline \multicolumn{7}{|l|}{ Bankruptcy characteristics } \\
\hline \multirow[t]{2}{*}{ During bankruptcy } & 0.078 & $1.258^{* * *}$ & 0.086 & $1.290^{* * *}$ & 0.276 & $1.614^{* * *}$ \\
\hline & {$[0.175]$} & {$[0.306]$} & {$[0.175]$} & {$[0.307]$} & {$[0.214]$} & {$[0.376]$} \\
\hline Prepack & $0.317^{*}$ & 0.030 & $0.328^{*}$ & 0.064 & & \\
\hline & {$[0.173]$} & {$[0.338]$} & {$[0.173]$} & {$[0.340]$} & & \\
\hline DIP financing & 0.315 & $1.059^{* *}$ & 0.329 & $1.112^{* * *}$ & 0.149 & $1.598^{* * *}$ \\
\hline & {$[0.209]$} & {$[0.422]$} & {$[0.209]$} & {$[0.430]$} & {$[0.298]$} & {$[0.607]$} \\
\hline Fraud & 0.544 & $1.525^{* * *}$ & 0.552 & $1.618^{* * *}$ & 0.436 & $2.439^{* * *}$ \\
\hline & {$[0.360]$} & {$[0.493]$} & {$[0.361]$} & {$[0.496]$} & {$[0.485]$} & {$[0.635]$} \\
\hline $\begin{array}{l}\text { P-value, Founder incumbent } \\
\text { versus Nonfounder incumbent }\end{array}$ & & & $(0.357)$ & $(0.056)$ & $(0.180)$ & $(0.056)$ \\
\hline Pseudo- $R^{2}$ & & & & & & \\
\hline Firm-years & & & & & & \\
\hline
\end{tabular}


Table 7

Determinants of the probabilities of chief executive officer (CEO) employment change around bankruptcy filing. The table shows coefficient estimates from multinomial logit regressions for the probabilities of chief executive officer (CEO) turnover and new executive employment after departure over the event period $(-2$, Emergence +1$)$, in firms filing for Chapter 11 in 1996-2007. The dependent variable has three outcomes: turnover with new executive position, turnover with no new executive position, and no turnover (the baseline outcome). Included but not reported are Fama and French 12 industry dummies and the regression constant term. The sample contains of 1,187 firm-years for 314 unique firms, of which 829 firm-years represent non-prepack filings. Standard errors are in square brackets. ${ }^{* * *},{ }^{* *}$, and ${ }^{*}$ denote significance at the $1 \%, 5 \%$, and $10 \%$ level, respectively. The $\mathrm{P}$-values in parentheses are from a $\chi^{2}$ test for the difference in the coefficients for Founder incumbent and Nonfounder incumbent. All variables are defined in Table 2.

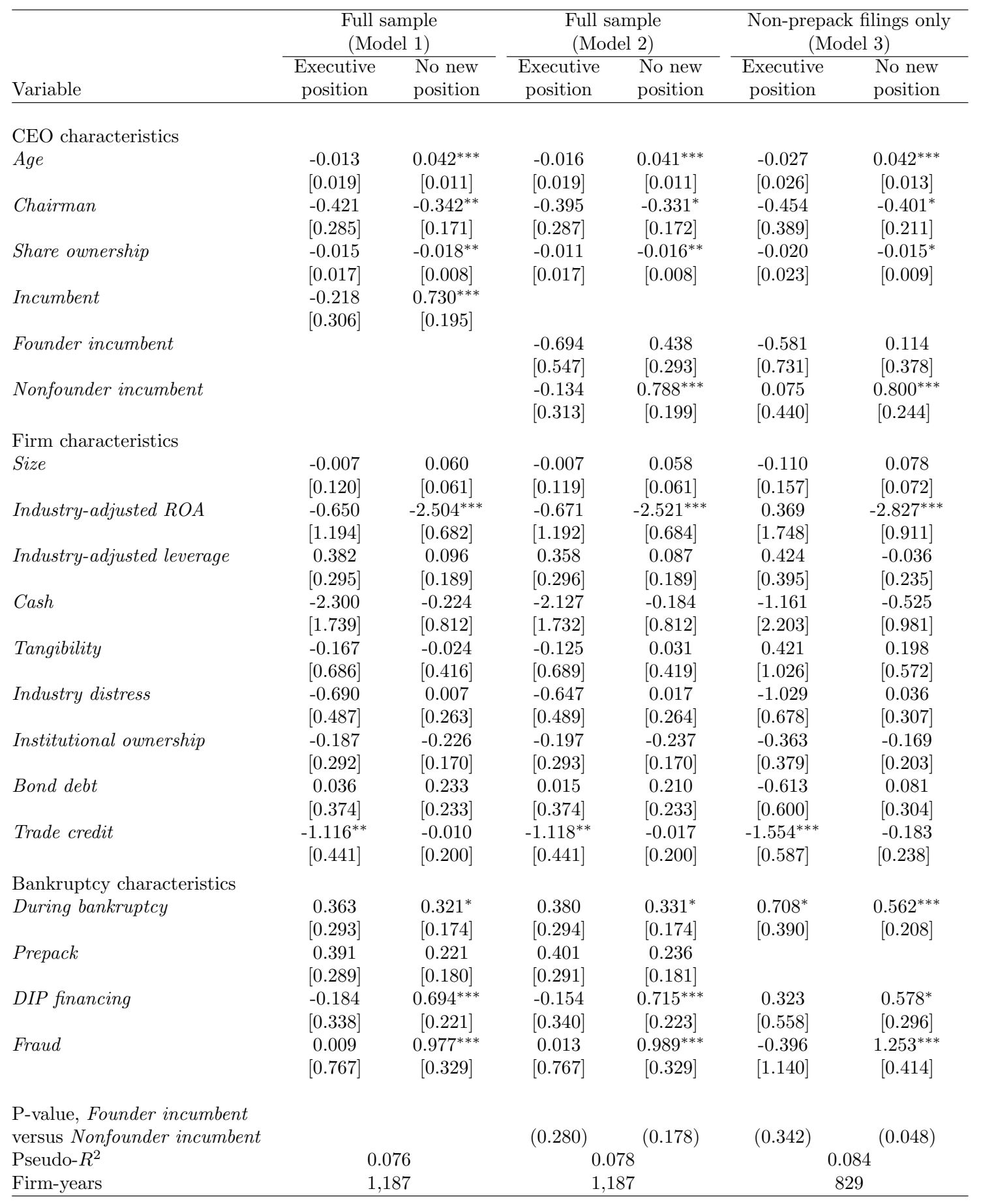




\section{Table 8}

Methodology for estimating chief executive officer (CEO) compensation from new employment around bankruptcy. The table describes the methodology used to estimate the CEO's compensation in his new employment, which includes remaining at the restructured firm after emerging from bankruptcy (see Fig. 1). The industry-size match used for private firms in Panel B is as follows: The sales of the matched firm in ExecuComp must be within 30\% of the private firm's sales. If sales are missing for the private firm, or no ExecuComp firm in the two-digit industry has sales within the $30 \%$ band, the private firm is matched on assets using the same algorithm. If information on assets is also missing, the match is on the number of employees. The sample size $N$ indicates the number of cases in each category after 63 cases with missing pre-departure total compensation are eliminated. The sample is 544 CEOs of 319 large public firms filing for Chapter 11 from 1996 to 2007.

\begin{tabular}{lll}
\hline Type of new employment & $N$ & Methodology for estimating income at the new firm
\end{tabular}

Panel A: Executive at public firm

Remain CEO at restructured firm emerging as public company

CEO at new public firm

NonCEO executive at new public firm

Panel B: Executive at private firm Remain CEO at restructured firm emerging as private stand-alone firm $\mathrm{CEO}$ at new private firm

NonCEO executive at new private firm

Panel C: No new executive position Nonexecutive director

Consultant or self-employed

No new employment
78 Actual compensation reported in ExecuComp, 10Ks or proxies. Average of the pay in years Emergence +1 and Emergence +2 if available, or else the pay in Emergence+1.

20 Actual compensation reported in ExecuComp, 10Ks or proxies. Average of the pay in the first two years of employment at the new firm.

12 Average of the actual compensation in the first two years of employment at the new firm from proxies or $10-\mathrm{Ks}$, or average pay for the new firm's nonCEO executives from ExecuComp.

57 CEO pay for an industry-size matched firm in ExecuComp in year Emergence+1, adjusted with a $20 \%$ private-firm discount.

38 CEO pay for an industry-size matched firm in ExecuComp in the first year of employment at the new firm, adjusted with a $20 \%$ private-firm discount.

28 NonCEO executive pay for an industry-size matched firm in ExecuComp in the first year of employment at the new firm, adjusted with a $20 \%$ private-firm discount.

Director pay estimated using regressions models 1-3 in Subsection 5.2, where the dependent variable is the average annual non-executive director pay for firms in ExecuComp, 2005-2012. Director pay estimate is the predicted value of one of the regression models, as indicated in the text.

66 Total pay of $\$ 500,000$ in 2009 dollars.

170 An income of zero. 


\section{Table 9}

Median severance paid to chief executive officers (CEOs) departing around bankruptcy filing.

The table shows the median severance pay for departed CEOs in thousands of constant 2009 dollars, conditional on receiving severance. Severance can be contractual or discretional, with discretional severance negotiated at the time of departure. Total severance is reported in thousands of dollars and in percent of the CEO's compensation in the year prior to departure. The sample contains 447 departed CEOs at 277 large public US firms filing for Chapter 11 in the 1996 tot 2007 period who leave their positions in $(-2$, Emergence +1$)$. All variables are defined in Table 2. The P-values in parenthesis are from Wilcoxon signed-rank tests for the difference in median. Data are from 10Ks, proxy statements, and news searches in Factiva.

\begin{tabular}{|c|c|c|c|c|c|c|}
\hline \multirow[b]{2}{*}{ Sample } & \multirow[b]{2}{*}{$N$} & \multirow{2}{*}{$\begin{array}{l}\text { Percent of CEOs who } \\
\text { receive severance }\end{array}$} & \multirow{2}{*}{$\begin{array}{c}\text { Contractual } \\
\text { severance }\end{array}$} & \multirow{2}{*}{$\begin{array}{c}\text { Discretional } \\
\text { severance }\end{array}$} & \multicolumn{2}{|c|}{ Total severance } \\
\hline & & & & & Dollars & Percent \\
\hline All departed CEOs & 447 & 28 & 539 & 396 & 1,635 & 300 \\
\hline \multicolumn{7}{|c|}{ Severance categorized by subsequent employment } \\
\hline New full-time executive position & 115 & 37 & 806 & 314 & 2,027 & 211 \\
\hline No new executive position & 332 & 24 & 405 & 481 & 1,604 & 347 \\
\hline P-value of difference & & $(0.006)$ & $(0.392)$ & $(0.341)$ & $(0.701)$ & $(0.328)$ \\
\hline \multicolumn{7}{|c|}{ Severance categorized by incumbent versus replacement CEOs } \\
\hline Incumbent CEO & 277 & 29 & 432 & 533 & 1,997 & 344 \\
\hline Replacement CEO & 170 & 25 & 667 & 44 & 1,277 & 229 \\
\hline P-value of difference & & $(0.411)$ & $(0.708)$ & $(0.045)$ & $(0.102)$ & $(0.368)$ \\
\hline \multicolumn{7}{|c|}{ Severance categorized by forced versus voluntary turnover } \\
\hline Forced turnover & 79 & 43 & 995 & 1,241 & 2,912 & 502 \\
\hline Voluntary turnover & 368 & 24 & 452 & 313 & 1,290 & 225 \\
\hline $\mathrm{P}$-value of difference & & $(0.001)$ & $(0.293)$ & $(0.027)$ & $(0.002)$ & $(0.014)$ \\
\hline
\end{tabular}


Table 10

Median chief executive officer (CEO) compensation change around bankruptcy filing.

The table shows the median CEO compensation change (in thousands of dollars and percent) and present value (PV) compensation change (in thousands of dollars and as a multiple of the CEO's old compensation). Compensation change is the difference between the old income and new income, where the new income is estimated as described in Table 8. For incumbent CEOs, the old compensation is averaged over years -3 and -2 (or, when the income in year -3 is missing, it is the income in year -2 only). For the replacement CEOs, the old compensation is averaged over the hiring year and the next (or, when the income in the next year is missing, it is the income in the hiring year only). PV compensation change is the present value of the compensation change through age 65 , discounted at a $10 \%$ rate, and adjusted for severance pay and time to new employment. The sample is 544 CEOs of 319 large public US firms filing for Chapter 11 bankruptcy from 1996 to 2007. ${ }^{* * *},{ }^{* *}$, and ${ }^{*}$ denote significance from zero at the $1 \%, 5 \%$, and $10 \%$ level, respectively. The P-values are from Wilcoxon signed-rank tests of the difference in median between incumbent CEOs and replacement CEOs.

\begin{tabular}{|c|c|c|c|c|}
\hline \multirow{2}{*}{\multicolumn{2}{|c|}{$N$}} & \multicolumn{2}{|c|}{ Median compensation change } & Median PV compensation change \\
\hline & & Thousands of dollars & Percent & Thousands of dollars \\
\hline
\end{tabular}

All CEOs maintaining executive employment

Incumbent CEOs $\quad 98 \quad-51$

Replacement CEOs $\quad 135 \quad 262^{*}$

(3)

(4)

(5)

$\mathrm{P}$-value of difference

$(0.052)$

$\begin{array}{ccc}-5 & 0 & 0.0 \\ 24^{* * *} & 674^{*} & 0.8^{* * *} \\ (0.050) & (0.111) & (0.098)\end{array}$

CEOs remaining at restructured firm in Emergence+1

Incumbent CEOs $\quad 44$

Replacement CEOs

$\mathrm{P}$-value of difference

91

$$
171
$$

262

$(0.583)$

CEOs departing to new executive position

$\begin{array}{lcc}\text { Incumbent CEOs } & 54 & -272 \\ \text { Replacement CEOs } & 44 & 214 \\ \text { P-value of difference } & & (0.046)\end{array}$

$\mathrm{P}$-value of difference

$\begin{array}{ccc}27 & 810 & 1.1^{* *} \\ 16^{* * *} & 652 & 0.8^{* *} \\ (0.616) & (0.782) & (0.690)\end{array}$

$-22$

$38^{* * *}$

$(0.056)$

$-1,102^{*}$

1,040

$(0.037)$

$-1.5$

$2.1^{* *}$

$(0.032)$

CEOs leaving the executive labor market

\begin{tabular}{lccccc} 
Incumbent CEOs & 213 & $-1,609^{* * *}$ & $-100^{* * *}$ & $-7,235^{* * *}$ & $-4.6^{* * *}$ \\
Replacement CEOs & 98 & $-1,208^{* * *}$ & $-100^{* * *}$ & $-5,277^{* * *}$ & $-5.3^{* * *}$ \\
P-value of difference & & $(0.073)$ & $(0.831)$ & $(0.702)$ & $(0.168)$ \\
\hline
\end{tabular}




\section{Table 11}

Determinants of the compensation change for chief executive officers (CEOs) maintaining executive employment around bankruptcy.

The table shows coefficient estimates from quantile (median) regressions of the compensation change (new minus old compensation) for CEOs maintaining executive employment at the restructured firm emerging from bankruptcy or at a new firm. The dependent variable is the percent compensation in Columns 1-4 and the present value (PV) of the compensation change as a multiple of the old compensation in Columns 5-8. The firm and bankruptcy characteristics are the same as in Table 6. The sample contains 231 CEOs of large public US firms filing for Chapter 11 from 1996 to 2007. Included but not reported are Fama and French 12 industry dummies and the regression constant term. Standard errors are in brackets. ${ }^{* * *}$, **, and ${ }^{*}$ denote significance at the $1 \%, 5 \%$, and $10 \%$ level, respectively. The P-values in parentheses are from a $\chi^{2}$ test for the difference in the coefficients for Founder incumbent and Nonfounder incumbent. All variables are defined in Table 2 .

\begin{tabular}{|c|c|c|c|c|c|c|c|c|}
\hline \multirow[b]{2}{*}{ Variable } & \multicolumn{4}{|c|}{ Percent compensation change } & \multicolumn{4}{|c|}{ PV compensation multiple } \\
\hline & (1) & $(2)$ & (3) & (4) & (5) & (6) & (7) & (8) \\
\hline Age & $\begin{array}{l}-0.003 \\
{[0.013]}\end{array}$ & $\begin{array}{l}-0.001 \\
{[0.015]}\end{array}$ & $\begin{array}{l}-0.003 \\
{[0.013]}\end{array}$ & $\begin{array}{c}0.002 \\
{[0.017]}\end{array}$ & $\begin{array}{l}-0.024 \\
{[0.091]}\end{array}$ & $\begin{array}{c}0.017 \\
{[0.089]}\end{array}$ & $\begin{array}{l}-0.031 \\
{[0.091]}\end{array}$ & $\begin{array}{c}0.017 \\
{[0.093]}\end{array}$ \\
\hline Chairman & $\begin{array}{l}-0.292 \\
{[0.197]}\end{array}$ & $\begin{array}{l}-0.310 \\
{[0.237]}\end{array}$ & $\begin{array}{l}-0.318 \\
{[0.199]}\end{array}$ & $\begin{array}{l}-0.284 \\
{[0.260]}\end{array}$ & $\begin{array}{l}-1.692 \\
{[1.393]}\end{array}$ & $\begin{array}{l}-1.877 \\
{[1.382]}\end{array}$ & $\begin{array}{l}-1.525 \\
{[1.393]}\end{array}$ & $\begin{array}{l}-1.700 \\
{[1.443]}\end{array}$ \\
\hline Incumbent & $\begin{array}{c}-0.452^{* *} \\
{[0.219]}\end{array}$ & $\begin{array}{l}-0.389 \\
{[0.281]}\end{array}$ & & & $\begin{array}{l}-1.873 \\
{[1.552]}\end{array}$ & $\begin{array}{c}0.287 \\
{[1.639]}\end{array}$ & & \\
\hline Founder incumbent & & & $\begin{array}{l}-0.507 \\
{[0.390]}\end{array}$ & $\begin{array}{l}-0.132 \\
{[0.513]}\end{array}$ & & & $\begin{array}{l}-2.377 \\
{[2.721]}\end{array}$ & $\begin{array}{l}1.030 \\
{[2.837]}\end{array}$ \\
\hline Nonfounder incumbent & & & $\begin{array}{l}-0.426^{*} \\
{[0.225]}\end{array}$ & $\begin{array}{l}-0.384 \\
{[0.313]}\end{array}$ & & & $\begin{array}{l}-1.817 \\
{[1.579]}\end{array}$ & $\begin{array}{l}-0.448 \\
{[1.738]}\end{array}$ \\
\hline Firm characteristics & & Yes & & Yes & & Yes & & Yes \\
\hline Bankruptcy characteristics & Yes & Yes & Yes & Yes & Yes & Yes & Yes & Yes \\
\hline $\begin{array}{l}\text { P-value, Founder incumbent } \\
\text { versus Nonfounder incumbent }\end{array}$ & & & $(0.832)$ & $(0.608)$ & & $(0.833)$ & $(0.588)$ & \\
\hline Pseudo- $\mathrm{R}^{2}$ & 0.014 & 0.045 & 0.042 & 0.046 & 0.014 & 0.040 & 0.014 & 0.040 \\
\hline Observations & 231 & 200 & 231 & 200 & 229 & 199 & 229 & 199 \\
\hline
\end{tabular}




\section{Table 12}

Determinants of chief executive officer (CEO) compensation prior to bankruptcy filing.

The table shows coefficient estimates from ordinary least squares (OLS) regressions for the logarithm of CEO compensation (Models 1 and 2) and from Tobit regressions for the fraction of the compensation paid in cash (Models 3 and 4). The sample contains 784 pre-filing firm-years $(-3,-1)$ of large public US firms filing for Chapter 11 from 1996-2007. Included but not reported are Fama and French 12 industry dummies and the regression constant term. Standard errors are in brackets. ${ }^{* * *}{ }^{* *}$, and ${ }^{*}$ denote significance at the 1\%,5\%, and 10\% level, respectively. The P-values in parentheses are from a $\chi^{2}$ test for the difference in the coefficients for Founder incumbent and Nonfounder incumbent. All variables are defined in Table 2 .

\begin{tabular}{|c|c|c|c|c|}
\hline \multirow[b]{2}{*}{ Variable } & \multicolumn{2}{|c|}{ Compensation in dollars (OLS) } & \multicolumn{2}{|c|}{ Fraction paid in cash (Tobit) } \\
\hline & $(1)$ & $(2)$ & $(3)$ & $(4)$ \\
\hline \multicolumn{5}{|l|}{ CEO characteristics } \\
\hline \multirow{2}{*}{ Age } & $-0.025^{* * *}$ & $-0.024^{* * *}$ & $0.010^{* * *}$ & $0.009 \mathrm{y}$ \\
\hline & {$[0.007]$} & {$[0.007]$} & {$[0.002]$} & {$[0.002]$} \\
\hline \multirow{2}{*}{ Chairman } & 0.030 & 0.013 & $-0.089^{* *}$ & $-0.083^{* *}$ \\
\hline & {$[0.116]$} & {$[0.116]$} & {$[0.041]$} & {$[0.041]$} \\
\hline \multirow{2}{*}{ Share ownership } & $-0.008^{*}$ & $-0.009^{* *}$ & $0.010 \mathrm{y}$ & $0.010^{* * *}$ \\
\hline & {$[0.004]$} & {$[0.004]$} & [0.002] & {$[0.002]$} \\
\hline \multirow[t]{2}{*}{ Incumbent } & $0.433^{* * *}$ & & 0.065 & \\
\hline & {$[0.131]$} & & {$[0.046]$} & \\
\hline Founder incumbent & & $\begin{array}{c}0.620^{* * *} \\
{[0.181]}\end{array}$ & & $\begin{array}{l}-0.012 \\
{[0.063]}\end{array}$ \\
\hline Nonfounder incumbent & & $\begin{array}{c}0.394^{* * *} \\
{[0.133]}\end{array}$ & & $\begin{array}{l}0.082^{*} \\
{[0.047]}\end{array}$ \\
\hline \multicolumn{5}{|l|}{ Firm characteristics } \\
\hline Size & $\begin{array}{c}0.253^{* * *} \\
{[0.039]}\end{array}$ & $\begin{array}{c}0.254^{* * *} \\
{[0.039]}\end{array}$ & $\begin{array}{l}-0.024^{*} \\
{[0.014]}\end{array}$ & $\begin{array}{l}-0.024^{*} \\
{[0.014]}\end{array}$ \\
\hline Industry-adjusted $R O A$ & $\begin{array}{c}0.150 \\
{[0.531]}\end{array}$ & $\begin{array}{c}0.379 \\
{[0.531]}\end{array}$ & $\begin{array}{l}-0.094 \\
{[0.190]}\end{array}$ & $\begin{array}{l}-0.080 \\
{[0.190]}\end{array}$ \\
\hline Industry-adjusted leverage & $\begin{array}{l}-0.048 \\
{[0.175]}\end{array}$ & $\begin{array}{l}-0.028 \\
{[0.176]}\end{array}$ & $\begin{array}{c}0.179^{* * *} \\
{[0.066]}\end{array}$ & $\begin{array}{c}0.172^{* * *} \\
{[0.066]}\end{array}$ \\
\hline Cash & $\begin{array}{l}1.085^{* *} \\
{[0.467]}\end{array}$ & $\begin{array}{l}1.019^{* *} \\
{[0.469]}\end{array}$ & $\begin{array}{l}-0.057 \\
{[0.164]}\end{array}$ & $\begin{array}{l}-0.029 \\
{[0.164]}\end{array}$ \\
\hline Tangibility & $\begin{array}{l}-0.182 \\
{[0.278]}\end{array}$ & $\begin{array}{l}-0.215 \\
{[0.279]}\end{array}$ & $\begin{array}{l}-0.017 \\
{[0.097]}\end{array}$ & $\begin{array}{l}-0.002 \\
{[0.097]}\end{array}$ \\
\hline Industry distress & $\begin{array}{c}-0.418^{* *} \\
{[0.178]}\end{array}$ & $\begin{array}{c}-0.426^{* *} \\
{[0.178]}\end{array}$ & $\begin{array}{c}0.100 \\
{[0.062]}\end{array}$ & $\begin{array}{l}0.103^{*} \\
{[0.062]}\end{array}$ \\
\hline \multicolumn{5}{|l|}{ Bankruptcy characteristics } \\
\hline Prepack & $\begin{array}{c}-0.380^{* * *} \\
{[0.117]}\end{array}$ & $\begin{array}{c}-0.396^{* * *} \\
{[0.118]}\end{array}$ & $\begin{array}{c}0.116^{* * *} \\
{[0.042]}\end{array}$ & $\begin{array}{c}0.122^{* * *} \\
{[0.042]}\end{array}$ \\
\hline Fraud & $\begin{array}{c}0.719^{* * *} \\
{[0.247]}\end{array}$ & $\begin{array}{c}0.710^{* * *} \\
{[0.247]}\end{array}$ & $\begin{array}{c}-0.350^{* * *} \\
{[0.084]}\end{array}$ & $\begin{array}{l}-0.346^{* * *} \\
{[0.084]}\end{array}$ \\
\hline $\begin{array}{l}\text { P-value, Founder incumbent } \\
\text { versus Nonfounder incumbent }\end{array}$ & & $(0.134)$ & & $(0.078)$ \\
\hline Adjusted $R^{2} /$ Pseudo- $R^{2}$ & 0.123 & 0.124 & 0.099 & 0.101 \\
\hline Firm-years & 784 & 784 & 784 & 784 \\
\hline
\end{tabular}

